\title{
Cationic Gemini Surfactants Based on Tartaric Acid: Synthesis, Aggregation, Monolayer Behaviour, and Interaction with DNA
}

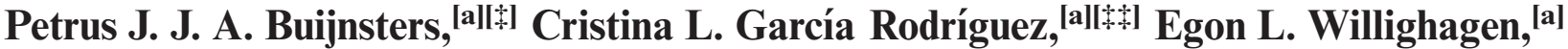

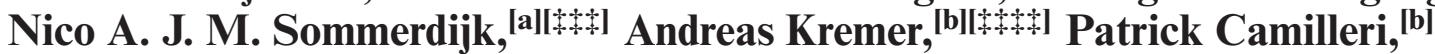 \\ Martinus C. Feiters, ${ }^{*[a]}$ Roeland J. M. Nolte, ${ }^{[a]}$ and Binne Zwanenburg ${ }^{[a]}$
}

Keywords: Gemini surfactant / Amphiphile / Monolayers / Circular dichroism

The synthesis of three novel cationic gemini surfactants (10, 12, and 14) based on tartaric acid appended with biocompatible palmitoyl tails and head groups is described, and their aggregation in water, monolayer behaviour, DNA binding, and gene transfection activities are reported. The monolayer studies showed that the molecular area of the surfactants is determined by the head group, as it increased going from the ethylenediamine head group of $\mathbf{1 0}$ via the lysine head group of 12 to the combined lysine/ethylenediamine head group of 14. Electron microscopy showed that the surfactants with the smaller head groups (10 and 12) form plate-like structures, probably stacked bilayers, in line with the shapestructure concept, whereas no structures are observed for the largest surfactant 14. A CD spectroscopic titration of $\lambda$-phage
DNA with surfactants 12 and 14 showed that there was some interaction, although the secondary structure of the DNA was hardly affected. The effects of the novel surfactants and commercially available DOTAP [N-(2,3-dioleoyloxypropyl)$N, N, N$-trimethylammonium methyl sulfate] were identical when compared on the basis of charge complimentarity, indicating that the complexation of DNA with the surfactant is a process of ion exchange. DNA binding was confirmed by the ability of all surfactants $(10,12$, and 14) to release ethidium bromide from its complex with DNA in an agarose gel electrophoresis experiment. Both lysine-containing surfactants 12 and 14 showed activity in a luciferase gene-transfection assay but this was accompanied by a considerable toxicity.

\section{Introduction}

Gemini surfactants are a relatively new class of amphiphilic molecules containing two head groups and two aliphatic chains, linked by a rigid ${ }^{[1,2]}$ or flexible spacer. ${ }^{[3,4]}$ They have physicochemical properties that are different from those of classical (single chain, single headgroup) surfactants, ${ }^{[5]}$ including low critical aggregate concentration values. It has recently been shown that cationic gemini surfactants can display high transfection activities, ${ }^{[6-8]}$ i.e. they can act as vehicles to introduce DNA across the mammalian cell membrane into the biological cell. This property is

[a] Department of Organic Chemistry, University of Nijmegen, 1 Toernooiveld, 6525 ED Nijmegen, The Netherlands Fax: (internat.) + 31-24/365-2929 E-mail: mcf@sci.kun.nl

[b] Glaxo SmithKline Pharmaceuticals, New Frontiers Science Park,

Third Avenue, Harlow, Essex, CM19 5AW, United Kingdom

[*] Present address: Department of Medicinal Chemistry, Janssen Research Foundation, Turnhoutseweg 30, 2340 Beerse, Belgium

[+*] Present address: DSM Deretil, Villaricos, 04618 Cuevas del Almanzora, Spain

[+t] Present address: Laboratory of Macromolecular and Organic Chemistry, Eindhoven University of Technology, P. O. Box 513, $5600 \mathrm{MB}$ Eindhoven, The Netherlands

[N+A] Present address: LION Bioscience AG, Waldhofer Strasse 98, 69213 Heidelberg, Germany of relevance for gene therapy, an approach to treat acquired and inherited diseases by introducing a correct copy of the defective gene into the cell. ${ }^{[9]}$ Viruses are the most effective transfection agents, ${ }^{[10]}$ but their application is not without risk for patients. ${ }^{[11]}$ Various classical cationic surfactants have been demonstrated to be effective in transfection, like DOTMA [ $N$-(2,3-dioleyloxypropyl)- $N, N, N$-trimethylammonium chloride, Figure 1], ${ }^{[12]}$ now commercially available as Lipofectin ${ }^{\mathrm{TM}}$, DOTAP [ $N$-(2,3-dioleoyloxypropyl)$\mathrm{N}, \mathrm{N}, \mathrm{N}$-trimethylammonium methyl sulfate] and LipofectAMINE $^{\text {TM }}$ \{based on DOSPA, $N$-(2,3-dioleoyloxypropyl)$N, N$-dimethyl- $N$-[2-(sperminecarboxamido)ethyl]ammonium trifluoroacetate, Figure 1\}. ${ }^{[13]}$ As the mechanism of gene transfer mediated by cationic surfactants is not fully understood, ${ }^{[14,15]}$ the strategy for the development is as yet merely empirical.

We have recently explored the preparation and physicochemical properties of various surfactants based on biocompatible building blocks ${ }^{[16]}$ including anionic gemini surfactants based on tartaric acid. ${ }^{[17-19]}$ The aforementioned developments in the field of gene transfection prompted us to explore the cationic analogues of such gemini surfactants, as they might be expected to combine transfection efficiency with biocompatibility and low toxicity. We present here a convenient synthesis of a series of new gemini sur- 

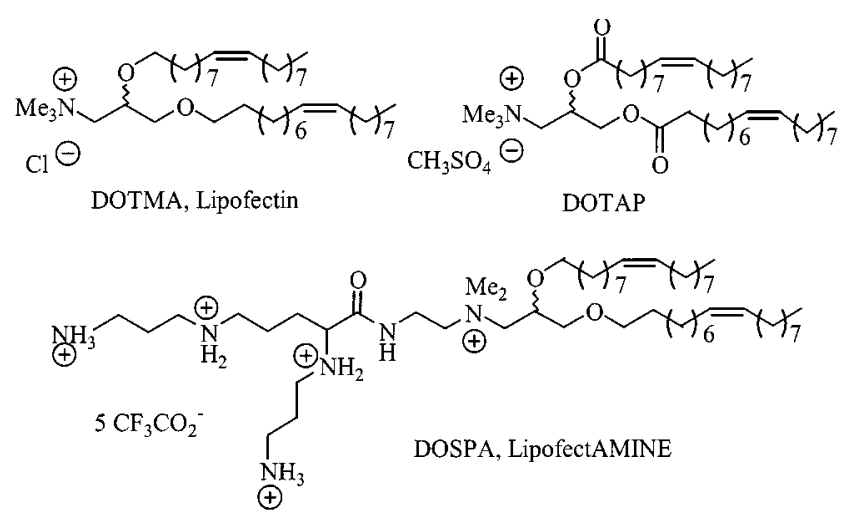

Figure 1. Structures of efficient surfactants for transfection

factants $(10,12$, and 14) based on tartaric acid, and the results of studies of the aggregation of the compounds in water and their interaction with DNA, along with an exploration of their transfection activity and toxicity.

\section{Results and Discussion}

\section{Synthesis}

The conversion of L-(+)-tartaric acid into the benzyl-protected diol 1 was performed by using a literature procedure. ${ }^{[20]}$ Subsequent introduction of the alkyl chains and catalytic removal of the benzyl groups afforded the key compound 3 in an overall yield of $85 \%$ (Scheme 1). The preparations of the protected head groups $\mathbf{6}$ and $\mathbf{8}$ started from commercially available $N^{\alpha}$-Boc- $N^{\varepsilon}$-Z-L-lysine (4, Scheme 1). Amine 6 was obtained by treatment of $\mathbf{4}$ with ethyl chloroformate and ammonia, followed ${ }^{[21]}$ by removal of the Boc group with trifluoroacetic acid. DCC coupling of $\mathbf{4}$ with benzyl $N$-(aminoethyl)carbamate and subsequent deprotection led to the amine 8. The DCC-assisted condensation of 3 with benzyl $N$-(aminoethyl)carbamate, followed by treatment of the resulting compound 9 with $\mathrm{HBr} /$ $\mathrm{AcOH}$, gave surfactant $\mathbf{1 0}$ in acceptable yield (Scheme 2). The preparation and isolation of the intermediates $\mathbf{1 1}$ and $\mathbf{1 3}$ by EDC coupling of $\mathbf{3}$ with $\mathbf{6}$ and $\mathbf{8}$, respectively, was rather troublesome. Therefore, it was decided to use these compounds without purification in the next step. Deprotection of $\mathbf{1 1}$ and $\mathbf{1 3}$ furnished the surfactants $\mathbf{1 2}$ and 14, respectively. They were fully characterized by ${ }^{1} \mathrm{H},{ }^{13} \mathrm{C}$ NMR and elemental analysis.

\section{Monolayer and Aggregation Behaviour}

Inspection of CPK models of the surfactants $\mathbf{1 0}$ and $\mathbf{1 2}$ revealed that the overall shape of these molecules is cylindrical, whereas for $\mathbf{1 4}$ the shape is cone-like. On the basis of the shape-structure concept, ${ }^{[22]}$ it was therefore expected that the compounds $\mathbf{1 0}$ and $\mathbf{1 2}$ would form bilayer aggregates ${ }^{[17,19]}$ upon dispersion in water, whereas compound $\mathbf{1 4}$ would form micellar structures. This was confirmed by examining sonicated dispersions of $\mathbf{1 0}$ and $\mathbf{1 2}$ in water at $\mathrm{pH}=7.0$ after $24 \mathrm{~h}$ at room temperature by using transmission electron microscopy (TEM). Plate-like structures were observed for $\mathbf{1 0}$ (Figure 2, left) and $\mathbf{1 2}$ (Figure 2, right), respectively. No distinct morphology was observed for gemini surfactant $\mathbf{1 4}$ indicating that the aggregates of this compound were too small to be observed with TEM, in line with the anticipated formation of micellar structures. There were also significant differences in the stabilities of the dispersions: $\mathbf{1 0}$ and $\mathbf{1 2}$ precipitated after $15 \mathrm{~min}$ and approximately $1 \mathrm{~d}$, respectively, whilst solutions of compound $\mathbf{1 4}$ remained homogeneous, even after two months.

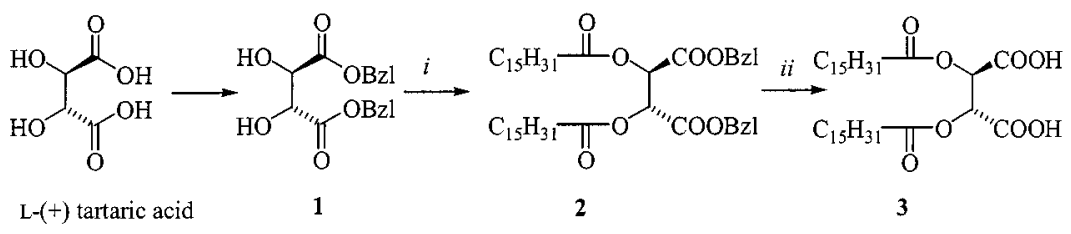

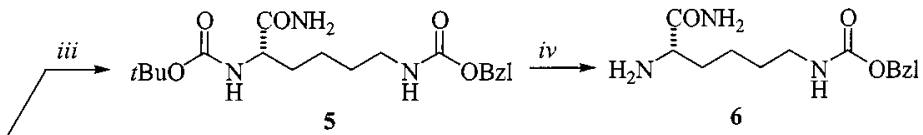

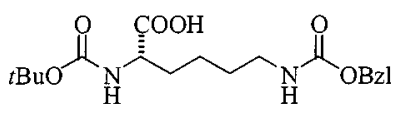

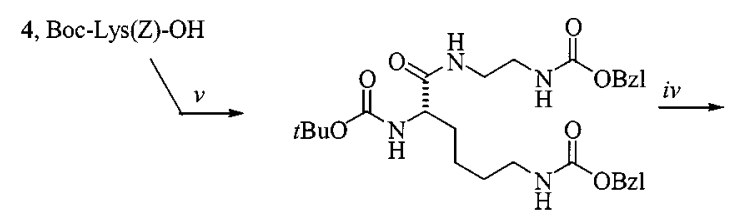

7

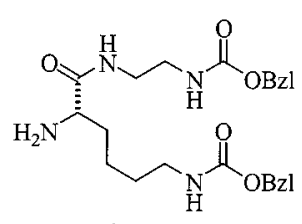

8

Scheme 1. (i) $\mathrm{C}_{15} \mathrm{H}_{31} \mathrm{COCl}, \mathrm{Et}_{3} \mathrm{~N}, \mathrm{DMAP}, \mathrm{CHCl}_{3}, 0{ }^{\circ} \mathrm{C} 1 \mathrm{~h}, 85 \%$; (ii) $\mathrm{Pd} / \mathrm{C} / \mathrm{H}_{2}, \mathrm{MeOH}, 2 \mathrm{~h}, 100 \%$; (iii) a. EtOCOCl, Et 3 N, THF, $-15^{\circ} \mathrm{C}, 1 \mathrm{~h}$; b. $\mathrm{NH}_{3}$ (aq), 1 h, room temp., 73\%; (iv) THF/TFA (4:1, v/v), $24 \mathrm{~h}, 61 \%$ (6), 85\% (8); (v) HOBT, benzyl $N$-(aminoethyl)carbamate, DCC, $\mathrm{CHCl}_{3}, 0{ }^{\circ} \mathrm{C}, 15 \mathrm{~min}, 24 \mathrm{~h}$, room temp., $80 \%$ 


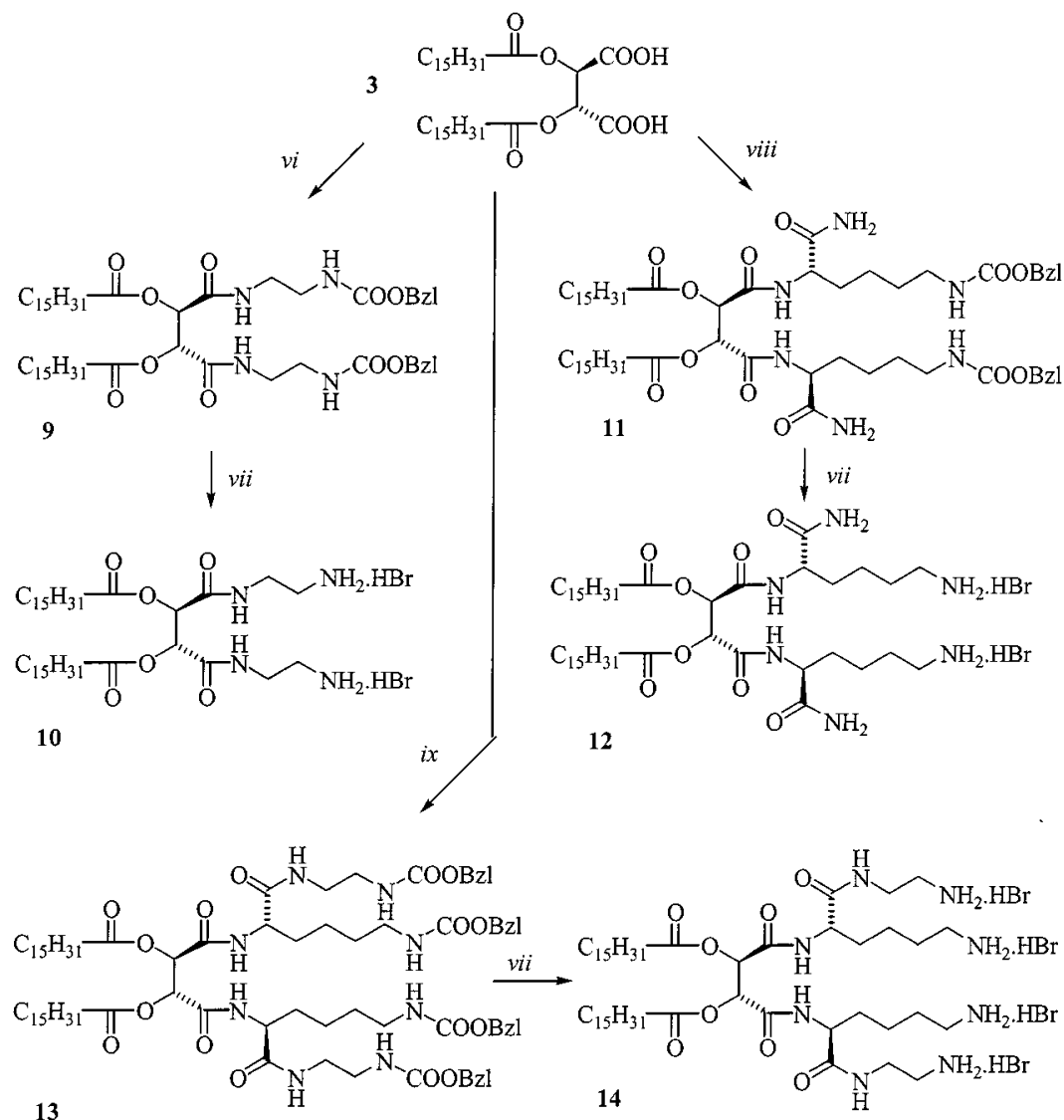

Scheme 2. (vi) 3, HOBT, benzyl $\mathrm{N}$-(aminoethyl)carbamate, DCC, $\mathrm{CHCl}_{3}, 0{ }^{\circ} \mathrm{C}, 15 \mathrm{~min}, 24 \mathrm{~h}$, room temp., 77\%; (vii) $\mathrm{HBr} / \mathrm{HOAc}$, room temp., $15 \mathrm{~min}, 53 \%(\mathbf{1 0}), 60 \%$ (12), 60\% (14); (viii) 3, $\mathrm{HOBT}, \mathrm{Et}_{3} \mathrm{~N}, \mathbf{6}, \mathrm{EDC}, \mathrm{CHCl}_{3}, 0{ }^{\circ} \mathrm{C}, 15 \mathrm{~min}, 24 \mathrm{~h}$ room temp., $27 \%$; (ix) 3, HOBT, $\mathrm{Et}_{3} \mathrm{~N}, 8, \mathrm{EDC}, \mathrm{CHCl}_{3}, 0{ }^{\circ} \mathrm{C}, 15 \mathrm{~min}, 24 \mathrm{~h}$, room temp., $60 \%$
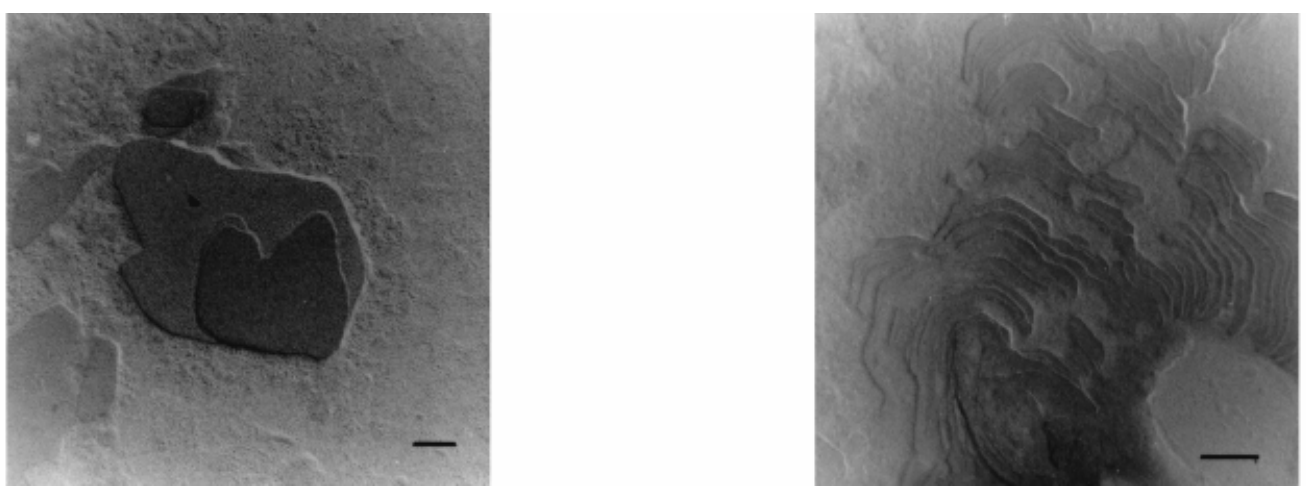

Figure 2. Electron micrographs of dispersions of (left) $\mathbf{1 0}$ and (right) 12 at pH = 7.0; bar represents $150 \mathrm{~nm}$

The film-forming capabilities of the gemini surfactants at the air/water interface were also investigated, viz. by monolayer studies in a Langmuir trough (Figure 3). Surfactant 10 formed a condensed film and the molecular area, determined by extrapolating the slope of the curve to zero pressure, is in good agreement with the molecular area derived from CPK models, namely ca. $50 \AA^{2} /$ molecule. The $\pi / \mathrm{A}$ isotherm of $\mathbf{1 2}$ showed a pressure fall when the surface area was decreased to $40 \AA^{2}$, whereas a normal increase in surface pressure was observed upon further compression. In the latter phase, Brewster angle microcopy (not shown) revealed a continuous densification and an increase in intens-

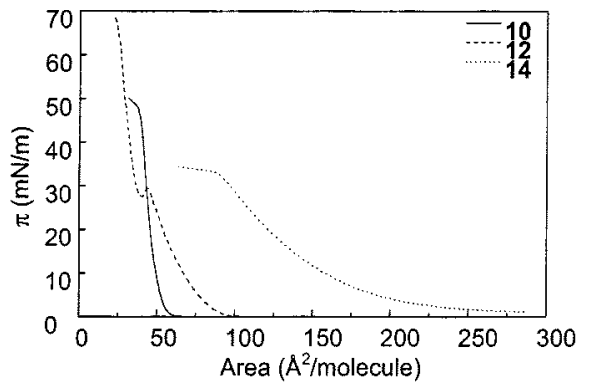

Figure 3. Monolayer isotherms of gemini surfactants 10, 12, and 14 recorded on a subphase of $\mathrm{pH}=7.0(10 \mathrm{~mm}$ PIPES $)$ at $20^{\circ} \mathrm{C}$ 
ity of the image. Since no abrupt pressure falls, which would have indicated a collapse, were observed, and the calculated molecular area was approximately $38-40 \AA^{2} /$ molecule, corresponding to the area of two alkyl chains, these observations suggest that $\mathbf{1 2}$ forms bilayers. A very large lift-off area of approximately $275 \AA^{2}$ was determined for $\mathbf{1 4}$ and no condensed phase was observed upon compression, indicating that the molecular shape was determined by the size of its head group. In previous studies from our laboratory ${ }^{[18,19]}$ on anionic analogues of $\mathbf{1 0}, \mathbf{1 2}$, and $\mathbf{1 4}$ it was demonstrated that Newman projections along the $\mathrm{C} 2-\mathrm{C} 3$ bond of the tartaric acid can provide insight into the most favourable spatial orientation of the substituents on the carboxylic acid function. Conformations in which the long tails are antiperiplanar should be neglected, since these are unfavourable in terms of hydrocarbon chain organization. According to this analysis the head groups of compound $\mathbf{1 0}$ can be expected to have either a gauche or anti orientation (Figure 4, $i$ and $i i)$. The latter, although sterically more demanding, will be more favourable, because of its lower degree of charge repulsion. The aliphatic moiety between the primary amide and the ammonium group of $\mathbf{1 2}$ possesses more flexibility than the corresponding moiety in $\mathbf{1 0}$, and as a consequence, the head groups of $\mathbf{1 2}$ are less restricted in their orientations allowing both a gauche and an anti conformation (Figure 4, iii and iv). For $\mathbf{1 4}$ probably only the anti conformation is allowed due to the bulkiness and the unfavourable charge repulsion of the head groups (Figure $4, v$ ), leading to a film in which the surfactants require a large surface area.

\section{Circular Dichroism Measurements on the Complexes}

To determine whether structural changes occur upon binding of cation surfactants to DNA, circular dichroism
(CD) experiments were performed. Nucleic acids are polymorphic in secondary structures, ${ }^{[23-25]}$ i.e. the number of base pairs per turn, the inclination of the bases with respect to the helical axis as well as the handedness of the helix depend on the solvent conditions. CD spectra of DNA strongly depend on the interactions of the complementary bases and are therefore very sensitive to the secondary structure of the nucleic acid. ${ }^{[26]} \mathrm{CD}$ experiments were conducted on solutions of double-stranded $\lambda$-phage DNA containing various concentrations of gemini surfactants $\mathbf{1 2}$ and 14. Due to the aforementioned instability of aqueous dispersions of $\mathbf{1 0}$ it was not possible to obtain reproducible $\mathrm{CD}$ results for this compound. For comparison commercially available surfactant DOTAP, ${ }^{[27-30]}$ which is known to bind to the DNA, was also studied. The $\lambda$-phage DNA displayed in its $\mathrm{CD}$ spectrum the typical B-form signature $^{[31,32]}$ of a positive band centered near $278 \mathrm{~nm}$, a negative band near $245 \mathrm{~nm}$ and a crossover point at ca. $258 \mathrm{~nm}$, the latter corresponding to the wavelength maximum in the UV spectrum (Figure 5a). The intensity of the peaks at 278 and at $245 \mathrm{~nm}$ decreased when the concentrations of compounds 12, 14, and DOTAP were increased going from an ammonium/phosphate charge ratio of 0 to approximately 4 (Figure $5 b-d$ ). The changes in the intensity of the CD peak centered at $278 \mathrm{~nm}$ have been associated with alterations of hydration shell of the DNA helix in the vicinity of the phosphate or the ribose ring when ionic concentrations are modified. ${ }^{[33]}$ It is reasonable to assume that cationic surfactants will exchange with sodium ions present on the DNA surface, which in turn will lead to changes in the hydration shell near the phosphate groups. The decrease in the CD intensity is small, suggesting that hydration changes are small. Thus, there is no major change in conformation of the secondary structure of the DNA upon binding of the
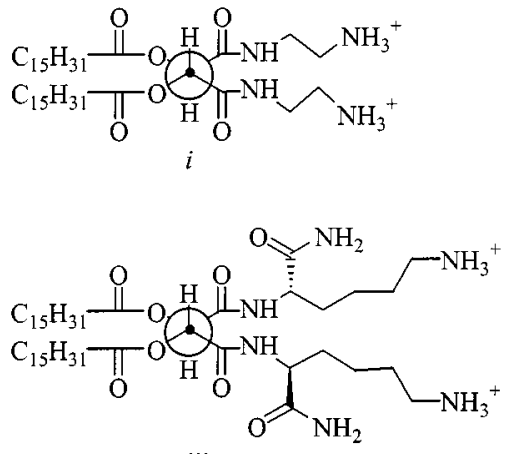

iii
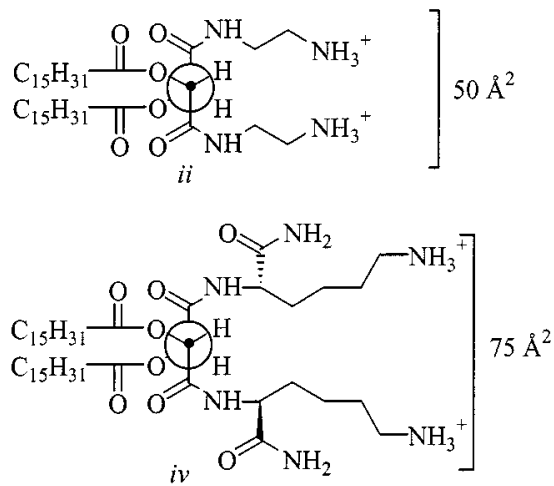

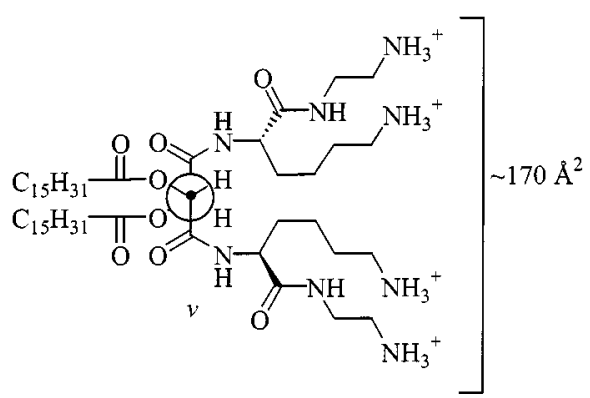

Figure 4. Newman projections of $\mathbf{1 0}(i, i i), \mathbf{1 2}(i i i, i v)$, and $\mathbf{1 4}(v)$ 

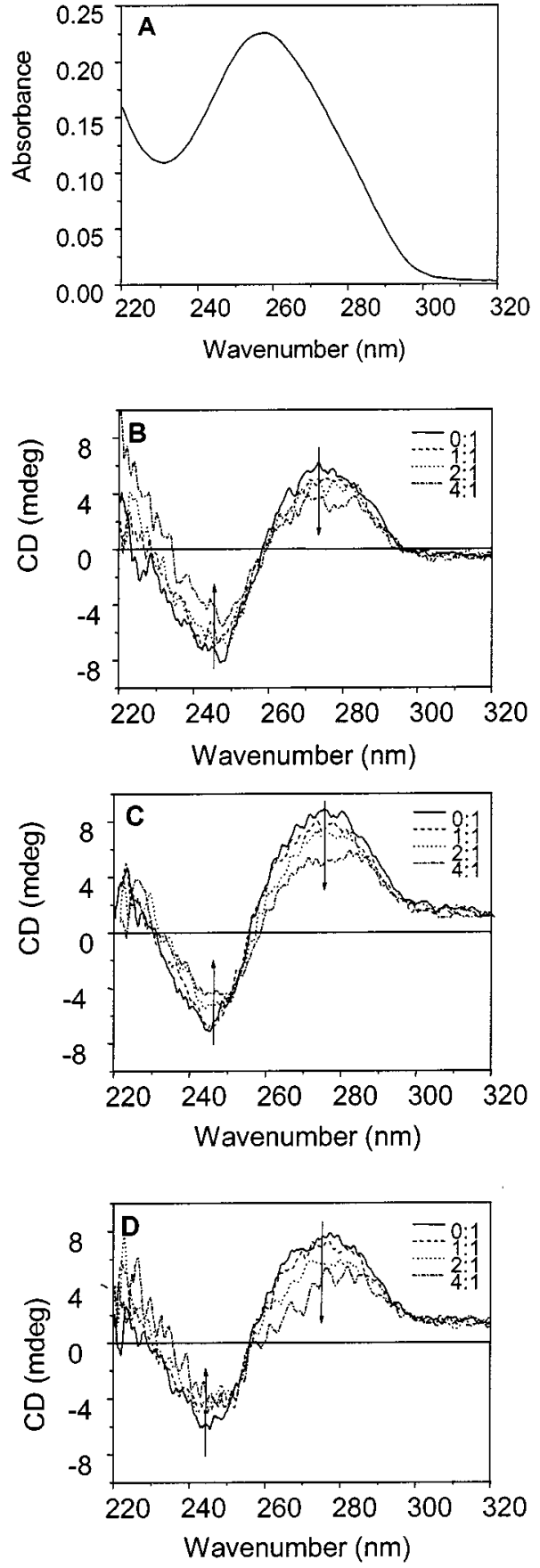

Figure 5. (A) UV spectrum of $\lambda$-phage DNA; (B) circular dichroism spectra of $\lambda$-phase DNA with increasing amounts of $\mathbf{1 2}$ at $\mathrm{pH}=7.0$ (10 mM PIPES); circular dichroism spectra of $\lambda$-phage DNA in aqueous $10 \mathrm{~mm}$ PIPES containing various amounts of (C) 14 and (D) DOTAP at $\mathrm{pH}=7.0,25^{\circ} \mathrm{C}$

surfactants to the duplex. When comparing our results to those of a study of the interaction of classical lipids with DNA, ${ }^{[34]}$ where it was found that only bilayer-forming lipids brought about conformational change, the lack of such an effect is not unexpected for the non-bilayer compound 14, whereas it would have been expected for the bilayer-forming 12. We note, however, that in our study DOTAP does not induce a conformational change either, contrary to earlier reports in the literature. ${ }^{[35]}$ The difference
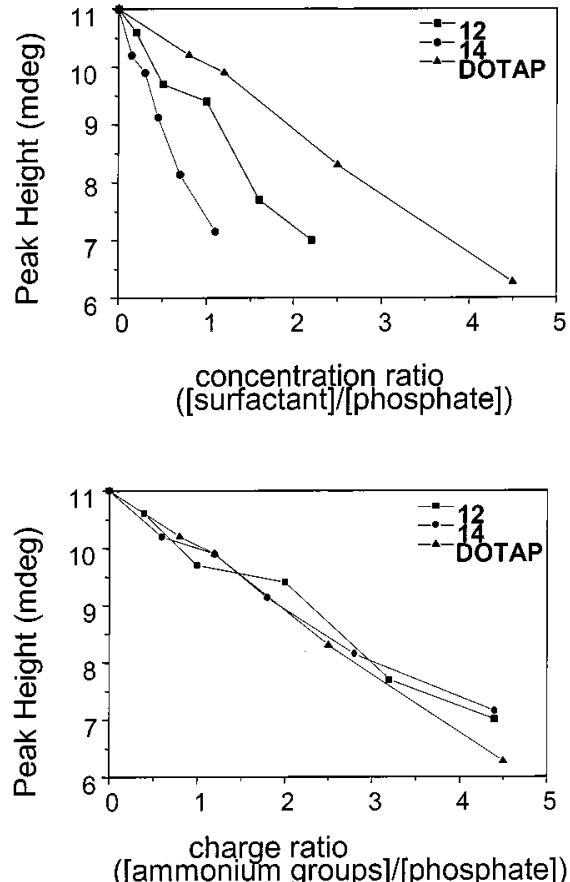

Figure 6. Peak height of the $\mathrm{CD}$ band at $278 \mathrm{~nm}$ plotted against the [surfactant]/[phosphate] ratio (top) and the [ammonium]/[phosphate] (charge) ratio (bottom)

may be due to the fact that our titrations were carried out in water in the absence of salts; such circumstances are known to favour the B configuration of DNA. ${ }^{[35]}$

The intensity of the positive band at $278 \mathrm{~nm}$ was proportional to the amount of added surfactant. CD intensities were determined using curve fitting procedures and plotted against both the [surfactant]/[phosphate] ratio (Figure 6, top) and the [ammonium groups]/[phosphate] ratio (Figure 6, bottom). These curves show (after compensation for the number of charges per molecule) that the $\mathrm{CD}$ intensity decreases when the number of charges increases. No differences are observed between the surfactants tested, i.e. structural modifications going from DOTAP to surfactants $\mathbf{1 2}$ and $\mathbf{1 4}$ neither have an influence on the CD spectrum, nor on the $\mathrm{CD}$ intensities as a function of the concentration. Surfactant/DNA complexes with different ammonium/ phosphate ratios were investigated using transmission electron microscopy, but only ill-defined aggregates were observed.

\section{Gel Electrophoresis and Gene Transfection of the Cationic Surfactant/DNA Complexes}

To examine the complex formation of the gemini surfactants with the pCMV-luciferase plasmid DNA, which was used for the transfection experiments, varying amounts of the compounds 10, 12, and $\mathbf{1 4}$ were added to the DNA. The DNA was preincubated with a solution of the probe ethidium bromide (3,8-diamino-5-ethyl-6-phenylphenanthridium bromide), which gives a fluorescent complex with DNA, and the resulting mixtures were subjected to electrophoresis in agarose gel. After the gel electrophoresis 
of the resulting mixture, the loss of fluorescence was taken as a measure of the capacity of the gemini surfactant to liberate the probe from its complex with DNA. ${ }^{[6-8]}$ It was found that all gemini surfactants studied interact with the luciferase plasmid DNA; this is in line with the CD results for the complexation of compounds $\mathbf{1 2}$ and $\mathbf{1 4}$ by $\lambda$-phage DNA. Transfection experiments ${ }^{[6-8]}$ were carried out using CHO-K1 cells and the pCMV-luciferase plasmid DNA. Gene transfection activities for compound 10, 12, and $\mathbf{1 4}$ were characterized as I (not active), III (active), and III/IV (active), respectively. Compounds $\mathbf{1 2}$ and $\mathbf{1 4}$ were found to display more than average toxicity, resulting in death of up to $30 \%$ of the cells used in the transfection experiments. Such a high toxicity is not typical for cationic gemini surfactants ${ }^{[6-8]}$ and was not anticipated for $\mathbf{1 2}$ and $\mathbf{1 4}$ in view of the expected biocompatibility of the tartaric acid skeleton, the carboxylic acid tails, and the amino acid head groups. The toxicity could be due to the compounds themselves or to products resulting from biodegradation, e.g. the single alkyl chain product resulting from enzymic splitting of one of the ester bonds, which is likely to be the first target. By analogy to the single-chain phospholipids, the socalled lysophospholipids, such compounds could have an anomalously high toxicity due to their strong detergent properties. ${ }^{[36]}$ This possibility was not further investigated.

\section{Concluding Remarks}

Starting from L-tartaric acid three novel surfactants (10, 12, and 14) with palmitoyl tails and ammonium and/or amino acid head groups were conveniently synthesized in acceptable yields. Going from 10 to $\mathbf{1 2}$ and then to $\mathbf{1 4}$, the introduction of larger head groups is clearly detectable in the molecular area as derived from monolayer studies on a Langmuir film balance, and results in a change in the aggregate morphology of the surfactants, in line with the shape-structure $^{[22]}$ concept. Compounds $\mathbf{1 0}$ and $\mathbf{1 2}$ form stacked bilayers and precipitate from their aqueous dispersions in $15 \mathrm{~min}$ and approximately $1 \mathrm{~d}$, respectively, whereas aqueous dispersions of compound $\mathbf{1 4}$ are more stable but have no distinct morphology. CD spectroscopy showed that compounds 12 and 14 interacted with $\lambda$-phage DNA, although the changes induced in the DNA structure by the cationic surfactants were relatively small. The complexation of the DNA is determined by the charge of the surfactant molecule rather than by other details of the molecular structure, which is in line with a mechanism of complex formation by ion exchange, resulting in charge complimentarity between the DNA and the cationic surfactant molecules. The gemini surfactants $\mathbf{1 2}$ and $\mathbf{1 4}$ showed moderate activity as carriers for mediating gene transfer to cells, which is encouraging, whereas $\mathbf{1 0}$ was not active.

Thus far, little is known about the relation between the molecular structure of a vector and its related gene transfer activity. ${ }^{[13]}$ There must be a delicate balance, however, between the factors required for complexation of the cytofectin with DNA to provide a suitable carrier system, such as the charge complimentarity mentioned above, and those that are responsible for the disassembly of the complex when it arrives at its target site. In this respect it can be predicted that surfactants which display a high degree of self-organization will show less transfection activity. ${ }^{[3]}$ In the present study, compounds $\mathbf{1 0}$ and $\mathbf{1 2}$ were found to assemble into stacked bilayers, whereas $\mathbf{1 4}$ gave stable solutions with no defined aggregate morphology. It can therefore be concluded that these compounds do show an inverse correlation between degree of self-organization and transfection efficiency. Before generalizing these conclusions, however, one has to consider that the transfection results were complicated by unexpected toxicity effects. Further efforts in the development of biocompatible cationic gemini surfactants with lysine as the building block are in progress.

\section{Experimental Section}

General Remarks: Thin layer chromatography analyses were performed on Merck precoated silica gel 60 F254 plates $(0.25 \mathrm{~mm})$ using the solvent mixtures indicated and spots were visualized with $\mathrm{UV}$ and/or using ammonium molybdate $(25 \mathrm{~g} / \mathrm{L})$ and ceric ammonium sulfate $(10 \mathrm{~g} / \mathrm{L})$ in aqueous $10 \% \mathrm{H}_{2} \mathrm{SO}_{4}$. Flash column chromatography was performed on Merck kieselgel $60 \mathrm{H}$ $(0.005-0.040 \mathrm{~mm})$ using a pressure of ca. 0.5 bar and the eluents indicated. Melting points were measured with a Reichert thermopan microscope equipped with crossed polarizers. Optical rotations were determined at $20^{\circ} \mathrm{C}$ using a Perkin-Elmer automatic polarimeter, model 241. Routine FT-IR spectra were recorded using a Biorad WIN-IR FTS-25 single-beam spectrometer. ${ }^{1} \mathrm{H}$ NMR and ${ }^{13} \mathrm{C}$ NMR spectra were recorded with a Bruker AC 300 (300/ $75.1 \mathrm{MHz}$ ) spectrometer. ${ }^{1} \mathrm{H}$ and ${ }^{13} \mathrm{C}$ chemical shifts are given in ppm $(\delta)$ relative to $\mathrm{Me}_{4} \mathrm{Si}$ as internal standard. Mass spectra were recorded with a double-focusing VG 7070E spectrometer. Elemental analyses were determined with a Carlo Erba Instruments EA 1108 element analyser.

Chemicals: Diethyl ether was pre-dried with potassium hydroxide, then distilled from sodium/benzophenone. Dichloromethane and chloroform were distilled from $\mathrm{CaH}_{2}$. Ethyl acetate and hexane were distilled under reduced pressure using a rotary evaporator.

\section{Synthesis}

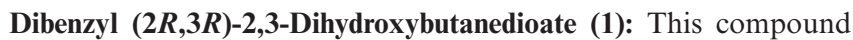
was prepared from L-(+)-tartaric acid by a literature procedure. ${ }^{[20]}$

Dibenzyl (2R,3R)-2,3-Bis(hexadecanoyloxy)butanedioate (2): A solution of $1(1.01 \mathrm{~g}, 3.1 \mathrm{mmol})$ in $\mathrm{CHCl}_{3}(20 \mathrm{~mL})$ with triethylamine $(1 \mathrm{~mL}, 7.2 \mathrm{mmol})$ and a catalytic amount of DMAP was gradually added to a cooled $\left(0^{\circ} \mathrm{C}\right)$ solution of hexadecanoyl chloride $(1.71 \mathrm{~g}$, $6.2 \mathrm{mmol})$ in $\mathrm{CHCl}_{3}(10 \mathrm{~mL})$. The reaction mixture was allowed to warm to room temperature and then stirred for a further $1 \mathrm{~h}$. The reaction mixture was diluted with $\mathrm{CHCl}_{3}$ and washed with $1.5 \mathrm{~N}$ $\mathrm{HCl}, 10 \%$ (w/v) $\mathrm{NaHCO}_{3}$ solution, brine, dried $\left(\mathrm{MgSO}_{4}\right)$, and concentrated in vacuo. The residue was recrystallized from acetonitrile to furnish $2.1 \mathrm{~g}(85 \%)$ of 3 as a white solid. M.p. $64.3-65.0{ }^{\circ} \mathrm{C}$. $[\alpha]_{\mathrm{D}}^{20}=+19.9\left(c=3.3, \mathrm{CHCl}_{3}\right) . \operatorname{IR}(\mathrm{KBr}): \tilde{v}=2917 \mathrm{~cm}^{-1}, 2850$ $(\mathrm{C}-\mathrm{H}$ alkyl $), 1770,1743(2 \times \mathrm{C}=\mathrm{O}), 1200,1160 \quad(2 \times$ alkyl-O-C). ${ }^{1} \mathrm{H}$ NMR (300 MHz, $\left.\mathrm{CDCl}_{3}\right): \delta=7.35-7.26(\mathrm{~m}, 10$ $\left.\mathrm{H}, 2 \times \mathrm{OCH}_{2} \mathrm{C}_{6} H_{5}\right), 5.74[\mathrm{~s}, 2 \mathrm{H}, 2 \times \mathrm{C}(\mathrm{O}) \mathrm{OCH}], 5.15(\mathrm{AB}, J=$ $\left.12.1 \mathrm{~Hz}, 4 \mathrm{H}, 2 \times \mathrm{OCH}_{2} \mathrm{C}_{6} \mathrm{H}_{5}\right), 2.33-2.08(\mathrm{~m}, 4 \mathrm{H}, 2 \times$ 
$\left.\mathrm{C}_{14} \mathrm{H}_{29} \mathrm{CH}_{2}\right), 1.54-1.49\left(\mathrm{~m}, 4 \mathrm{H}, 2 \times \mathrm{C}_{13} \mathrm{H}_{27} \mathrm{CH}_{2} \mathrm{CH}_{2}\right), 1.25(\mathrm{~m}$, $\left.48 \mathrm{H}, 2 \times \mathrm{CH}_{3} \mathrm{C}_{12} \mathrm{H}_{24} \mathrm{C}_{2} \mathrm{H}_{4}\right), 0.88\left(\mathrm{t}, J=6.4 \mathrm{~Hz}, 6 \mathrm{H}, 2 \times \mathrm{CH}_{3}\right)$. ${ }^{13} \mathrm{C}$ NMR $\left(75 \mathrm{MHz}, \mathrm{CDCl}_{3}\right): \delta=172.38[2 \times \mathrm{C}(\mathrm{O}) \mathrm{OCH}], 165.72$ $\left[2 \times \mathrm{CHC}(\mathrm{O}) \mathrm{OCH}_{2} \mathrm{C}_{6} \mathrm{H}_{5}\right], 134.77\left(2 \times\right.$ quat. $\left.C_{6} \mathrm{H}_{5}\right), 128.60,128.46$ $\left(o-, m-, p-C_{6} \mathrm{H}_{5}\right), 70.53[2 \times \mathrm{OCHC}(\mathrm{O})], 67.66\left(2 \times \mathrm{OCH}_{2} \mathrm{C}_{6} \mathrm{H}_{5}\right)$, $33.42\left[2 \times \mathrm{CH}_{2} \mathrm{C}(\mathrm{O}) \mathrm{O}\right], 31.91,29.70,29.47,29.37,29.24,28.95$, 24.57, $22.68\left(2 \times \mathrm{CH}_{3} \mathrm{C}_{13} \mathrm{H}_{26}\right), 14.01\left(2 \times \mathrm{CH}_{3}\right) \cdot \mathrm{C}_{50} \mathrm{H}_{78} \mathrm{O}_{8}$ (806.8): calcd. C 74.40, H 9.74; found C 73.64, H 9.76.

(2R,3R)-2,3-Bis(hexadecanoyloxy)butanedioic Acid (3): A solution of compound $2(1.20 \mathrm{~g}, 1.9 \mathrm{mmol})$ in ethyl acetate $(200 \mathrm{~mL})$ was subjected to catalytic hydrogenolysis $(\mathrm{Pd} / \mathrm{C})$ for $2 \mathrm{~h}$. The catalyst was removed by filtration using a small RP-18 column and washed with hot ethyl acetate, and the filtrate was concentrated in vacuo to give $1.19 \mathrm{~g}(100 \%)$ of 3. M.p. $131.5-132.2^{\circ} \mathrm{C}$. $[\alpha]_{\mathrm{D}}^{20}=-8.8(c=$ 5.2, $\left.\mathrm{CHCl}_{3}\right) . \operatorname{IR}(\mathrm{KBr}): \tilde{v}=3500-2700 \mathrm{~cm}^{-1}[\mathrm{C}(\mathrm{O})-\mathrm{OH}], 2916$, 2849 ( $\mathrm{CH}$ alkyl), $1748 \quad[(\mathrm{C}=\mathrm{O}) \mathrm{O}], 1728 \quad[\mathrm{C}(=\mathrm{O}) \mathrm{OH}], 1153$ $[\mathrm{C}(\mathrm{O})-\mathrm{O}-\mathrm{CH}] .{ }^{1} \mathrm{H}$ NMR $\left(300 \mathrm{MHz}, \mathrm{CDCl}_{3}\right): \delta=5.76[\mathrm{~s}, 2 \mathrm{H}, 2$ $\times \mathrm{C}(\mathrm{O}) \mathrm{OCHC}], 2.44\left[\mathrm{~m}, 4 \mathrm{H}, 2 \times \mathrm{CH}_{2} \mathrm{C}(\mathrm{O}) \mathrm{O}\right], 1.64[\mathrm{~m}, 4 \mathrm{H}, 2 \times$ $\left.\mathrm{CH}_{2} \mathrm{CH}_{2} \mathrm{C}(\mathrm{O}) \mathrm{O}\right], 1.25\left(\mathrm{~m}, 48 \mathrm{H}, 2 \times \mathrm{CH}_{3} \mathrm{C}_{12} \mathrm{H}_{24} \mathrm{C}_{2} \mathrm{H}_{4}\right), 0.88(\mathrm{t}$, $\left.J=6.3 \mathrm{~Hz}, 2 \times \mathrm{CH}_{3} \mathrm{C}_{14} \mathrm{H}_{28}\right) \cdot{ }^{13} \mathrm{C} \mathrm{NMR}\left(75 \mathrm{MHz}, \mathrm{CDCl}_{3}\right): \delta=$ $172.45[2 \times C(\mathrm{O}) \mathrm{OCH}], 170.28(2 \times \mathrm{COOH}), 70.02[2 \times$ $\mathrm{OCHC}(\mathrm{O})], 33.58\left[2 \times \mathrm{CH}_{2} \mathrm{C}(\mathrm{O}) \mathrm{O}\right], 31.92,29.70,29.47,29.36$, 29.22, 28.97, 24.65, 22.68, $\left(2 \times \mathrm{CH}_{3} \mathrm{C}_{13} \mathrm{H}_{26}\right), 14.01\left(2 \times \mathrm{CH}_{3}\right)$. $\mathrm{C}_{36} \mathrm{H}_{66} \mathrm{O}_{8}$ (626.7): calcd. C 68.97, H 10.61; found C 68.77, H 10.54.

Boc-L-Lys(Z)-NH $\mathbf{N H}_{2}$ (5): A stirred solution of Boc-L-Lys(Z)-OH (4, $4.0 \mathrm{~g}, 10.5 \mathrm{mmol})$ in dry THF $(70 \mathrm{~mL})$ was treated with triethylamine $(1.5 \mathrm{~mL})$. The reaction mixture was cooled to $-15^{\circ} \mathrm{C}$ and then treated with ethyl chloroformate $(1.4 \mathrm{~mL})$ and the solution was stirred for $1 \mathrm{~h}$ at room temperature. The mixture was treated with $25 \%(\mathrm{v} / \mathrm{v})$ aqueous ammonia $(6 \mathrm{~mL})$, stirred overnight at room temperature, and then concentrated in vacuo. The residue was dissolved in ethyl acetate and subsequently washed with $10 \%(\mathrm{w} / \mathrm{v})$ $\mathrm{Na}_{2} \mathrm{CO}_{3}$ solution, and brine, dried $\left(\mathrm{MgSO}_{4}\right)$, and concentrated in vacuo to give $2.91 \mathrm{~g}(73 \%)$ of $\mathbf{5} .{ }^{1} \mathrm{H}$ NMR $\left(300 \mathrm{MHz}, \mathrm{CDCl}_{3}\right): \delta=$ 7.35-7.30 (m, $5 \mathrm{H}, \mathrm{C}_{6} H_{5}$ ), 6.19 (br. s., $1 \mathrm{H}, \mathrm{NH}$ ), 5.34 (br. s., $1 \mathrm{H}$, $\mathrm{NH}$ ), 5.23 (br. s., $1 \mathrm{H}, \mathrm{NH}$ ), 5.09 (s, $2 \mathrm{H}, \mathrm{OCH}_{2} \mathrm{C}_{6} \mathrm{H}_{5}$ ), 4.92 (br. s., $1 \mathrm{H}, \mathrm{NH}), 4.10-4.08(\mathrm{~m}, 1 \mathrm{H}, \mathrm{CH}), 3.19[\mathrm{q}, J=6.1 \mathrm{~Hz}, 2 \mathrm{H}$, $\left.\left(\mathrm{CH}_{2}\right)_{3} \mathrm{CH}_{2}\right], 1.88-1.37\left[\mathrm{~m}, 6 \mathrm{H},\left(\mathrm{CH}_{2}\right)_{3} \mathrm{CH}_{2}\right], 1.43[\mathrm{~s}, 9 \mathrm{H}$, $\left.\left(\mathrm{CH}_{3}\right)_{3} \mathrm{C}\right] \cdot{ }^{13} \mathrm{C} \mathrm{NMR}\left(75 \mathrm{MHz}, \mathrm{CDCl}_{3}\right): \delta=175.45\left(\mathrm{CONH}_{2}\right)$, 156.08 [NHCOOBn, $\left(\mathrm{CH}_{3}\right)_{3} \mathrm{COCO}$ ], 137.04 (quat., $\left.C_{6} \mathrm{H}_{5}\right), 128.53$, $128.12\left(o-, m-, p-C_{6} \mathrm{H}_{5}\right), 79.47\left[\left(\mathrm{CH}_{3}\right)_{3} \mathrm{C}\right], 66.69\left(\mathrm{OCH}_{2} \mathrm{C}_{6} \mathrm{H}_{5}\right), 53.84$ $(\mathrm{CH}), 40.28\left[\left(\mathrm{CH}_{2}\right)_{3} \mathrm{CH}_{2}\right], 31.62,29.46,22.34\left[\left(\mathrm{CH}_{2}\right)_{3} \mathrm{CH}_{2}\right], 28.32$ $\left[\left(\mathrm{CH}_{3}\right)_{3} \mathrm{C}\right]$.

H-L-Lys(Z)-NH (6): Trifluoroacetic acid $(5 \mathrm{~mL})$ was added to a solution of $5(1.46 \mathrm{~g}, 13.8 \mathrm{mmol})$ in dry THF $(20 \mathrm{~mL})$ and the reaction mixture was stirred overnight at room temperature. The mixture was concentrated in vacuo and the residue was dissolved in $\mathrm{CH}_{2} \mathrm{Cl}_{2}$ and subsequently washed with $10 \%$ (w/v) $\mathrm{NaHCO}_{3}$ solution and brine, dried $\left(\mathrm{Na}_{2} \mathrm{SO}_{4}\right)$, and concentrated in vacuo to give $0.65 \mathrm{~g}(61 \%)$ of $6 .{ }^{1} \mathrm{H}$ NMR $\left(300 \mathrm{MHz}, \mathrm{CDCl}_{3}\right): \delta=7.45-7.36$ $\left(\mathrm{m}, 5 \mathrm{H}, \mathrm{C}_{6} H_{5}\right.$ ), 7.06 (br. s, $1 \mathrm{H}, \mathrm{NH}$ ), 5.45 (br. s, $2 \mathrm{H}, \mathrm{N} H_{2}$ ), 5.09 (s, $\left.2 \mathrm{H}, \mathrm{OCH}_{2}\right), 4.83$ (br. s, $\left.1 \mathrm{H}, \mathrm{NH}\right), 3.36(\mathrm{dd}, J=4.5,7.6 \mathrm{~Hz}, 1$ $\mathrm{H}, \mathrm{CH}), 3.24-2.99\left[\mathrm{~m}, 2 \mathrm{H}, \mathrm{CH}_{2} \mathrm{NHC}(\mathrm{O}) \mathrm{O}\right], 2.0-1.28[\mathrm{~m}, 6 \mathrm{H}$, $\left.\mathrm{CH}\left(\mathrm{CH}_{2}\right)_{3}\right] . \quad{ }^{13} \mathrm{C} \quad \mathrm{NMR} \quad\left(75 \mathrm{MHz}, \quad \mathrm{CDCl}_{3}\right): \quad \delta=177.90$ $\left[\mathrm{CH}_{2} \mathrm{C}(\mathrm{O}) \mathrm{NH}_{2}\right], 156.48$ [NHC(O)O], 136.59 (quat. $C_{6} \mathrm{H}_{5}$ ), 128.51 $\left(o, m-C_{6} \mathrm{H}_{5}\right), 128.09\left(p-C_{6} \mathrm{H}_{5}\right), 69.75\left(\mathrm{CH}_{2} \mathrm{O}\right), 58.80\left(\mathrm{CHNH}_{2}\right)$, $40.63\left(\mathrm{CH}_{2} \mathrm{NH}\right), 34.48\left(\mathrm{CH}_{2} \mathrm{CHNH}_{2}\right), 29.75\left(\mathrm{CH}_{2} \mathrm{CH}_{2} \mathrm{NH}\right), 22.75$ $\left(\mathrm{CH}_{2} \mathrm{CH}_{2} \mathrm{CH}_{2} \mathrm{NH}\right)$

Boc-L-Lys(Z)- $\left(\mathbf{C H}_{2}\right)_{2} \mathbf{N H}-\mathrm{Z}$ (7): A cooled $\left(0^{\circ} \mathrm{C}\right)$ solution of Boc-L$\mathrm{Lys}(\mathrm{Z})-\mathrm{OH}(2.5 \mathrm{~g}, 6.6 \mathrm{mmol})$ in $\mathrm{CHCl}_{3}(50 \mathrm{~mL})$ was treated with a solution of benzyl $\mathrm{N}$-(2-aminoethyl)carbamate $(2.3 \mathrm{~g}, 12.0 \mathrm{mmol})$ and 1-hydroxybenzotriazole $(1.78 \mathrm{~g}, 13.4 \mathrm{mmol})$, dissolved in $\mathrm{CHCl}_{3} \quad(20 \mathrm{~mL})$. DCC (dicyclohexylcarbodiimide, $2.78 \mathrm{~g}$, $13.4 \mathrm{mmol}$ ) was then added in small portions. The reaction mixture was stirred for $15 \mathrm{~min}$ at $0{ }^{\circ} \mathrm{C}$ and then overnight at room temperature. Subsequently it was filtered and the filtrate was concentrated in vacuo. Flash chromatography $\left(\mathrm{SiO}_{2}, \mathrm{CHCl}_{3} / \mathrm{MeOH}\right.$, gradient 99:1 to $95: 5)$ gave $2.94 \mathrm{~g}(80 \%)$ of $7 .{ }^{1} \mathrm{H}$ NMR $\left(300 \mathrm{MHz}, \mathrm{CDCl}_{3}\right)$ : $\delta=7.34-7.26\left(\mathrm{~m}, 10 \mathrm{H}, 2 \times \mathrm{C}_{6} H_{5}\right), 6.53$ (br. s, $\left.1 \mathrm{H}, \mathrm{NH}\right), 5.38$ (br. s, $1 \mathrm{H}, \mathrm{NH}$ ), 5.08 (s, $4 \mathrm{H}, 2 \times \mathrm{OCH}_{2} \mathrm{C}_{6} \mathrm{H}_{5}$ ), 4.90 (br. s, $1 \mathrm{H}$, $\mathrm{NH}), 3.98-3.94(\mathrm{~m}, 1 \mathrm{H}, \mathrm{CH}), 3.39-3.31\left[\mathrm{~m}, 4 \mathrm{H}, \mathrm{NH}\left(\mathrm{CH}_{2}\right)_{2} \mathrm{NH}\right]$, $3.17\left[\mathrm{q}, J=6.3 \mathrm{~Hz}, 2 \mathrm{H}, \mathrm{CH}\left(\mathrm{CH}_{2}\right)_{3} \mathrm{CH}_{2}\right], 1.67-1.25[\mathrm{~m}, 6 \mathrm{H}$, $\left.\mathrm{CH}\left(\mathrm{CH}_{2}\right)_{3} \mathrm{CH}_{2}\right], 1.42$ [s, $\left.9 \mathrm{H},\left(\mathrm{CH}_{3}\right)_{3} \mathrm{C}\right] .{ }^{13} \mathrm{C} \mathrm{NMR}(75 \mathrm{MHz}$, $\left.\mathrm{CDCl}_{3}\right): \delta=172.99(\mathrm{CHCONH}), 156.77,156.49,155.64[2 \times$ $\left.\mathrm{NHCOOC}_{6} \mathrm{H}_{5}, \mathrm{NHCOOC}\left(\mathrm{CH}_{3}\right)_{3}\right], 136.41,136.27$ (2 $\times$ quat. $\left.C_{6} \mathrm{H}_{5}\right), 128.20,127.76\left(2 \times o-, m-, p-C_{6} \mathrm{H}_{5}\right), 79.58\left[\left(\mathrm{CH}_{3}\right)_{3} C\right], 66.36$, $66.24\left(2 \times \mathrm{OCH}_{2} \mathrm{C}_{6} \mathrm{H}_{5}\right), \quad 54.32(\mathrm{CH}), \quad 40.46, \quad 40.18, \quad 39.42$ $\left[\mathrm{NH}\left(\mathrm{CH}_{2}\right)_{2} \mathrm{NH}, \quad \mathrm{CH}\left(\mathrm{CH}_{2}\right)_{3} \mathrm{CH}_{2}\right], \quad 31.84, \quad 29.08, \quad 22.31$ $\left[\mathrm{CH}\left(\mathrm{CH}_{2}\right)_{3} \mathrm{CH}_{2}\right]$.

H-L-Lys(Z)-( $\left.\mathbf{C H}_{\mathbf{2}}\right)_{\mathbf{2}} \mathbf{N H}-\mathbf{Z}$ (8): Compound $\mathbf{8}(2.05 \mathrm{~g}, 85 \%)$ was obtained from 7 (2.94 g, $5.3 \mathrm{mmol})$ in the manner as described for the preparation of 6 from $5 .{ }^{1} \mathrm{H} \mathrm{NMR}\left(300 \mathrm{MHz}, \mathrm{CDCl}_{3}\right): \delta=7.55$ (br. s, $1 \mathrm{H}, \mathrm{N} H), 7.34\left(\mathrm{~m}, 10 \mathrm{H}, 2 \times \mathrm{C}_{6} H_{5}\right), 5.32$ (br. s, $1 \mathrm{H}, \mathrm{NH}$ ), $5.08\left(\mathrm{~s}, 4 \mathrm{H}, 2 \times \mathrm{OCH}_{2} \mathrm{C}_{6} \mathrm{H}_{5}\right), 4.86$ (br. s, $\left.1 \mathrm{H}, \mathrm{NH}\right), 3.38-3.27$ $\left[\mathrm{m}, 6 \mathrm{H}, \mathrm{NH}\left(\mathrm{CH}_{2}\right)_{2} \mathrm{NH}, \mathrm{NHCHCONH}\right], 3.21-3.15[\mathrm{~m}, 2 \mathrm{H}$, $\left.\left(\mathrm{CH}_{2}\right)_{3} \mathrm{CH}_{2}\right], 1.79-1.29\left[\mathrm{~m}, 6 \mathrm{H}\left(\mathrm{CH}_{2}\right)_{3} \mathrm{CH}_{2}\right] .{ }^{13} \mathrm{C} \mathrm{NMR}(75 \mathrm{MHz}$, $\left.\mathrm{CDCl}_{3}\right): \delta=172.55(\mathrm{CHCONH}), 158.30,156.83 \quad(2 \times$ $\left.\mathrm{NHCOOC}_{6} \mathrm{H}_{5}\right), 136.57,136.49\left(2 \times\right.$ quat. $\left.C_{6} \mathrm{H}_{5}\right), 128.517,128.15$, $128.08,127.99,127.77\left(2 \times o-, \quad m-, \quad p-C_{6} \mathrm{H}_{5}\right), 66.70(2 \times$ $\left.\mathrm{OCH}_{2} \mathrm{C}_{6} \mathrm{H}_{5}\right), \quad 53.03 \quad(\mathrm{CHCONH}), \quad 41.35, \quad 40.60, \quad 39.29$ $\left[\mathrm{NH}\left(\mathrm{CH}_{2}\right)_{2} \mathrm{NH},\left(\mathrm{CH}_{2}\right)_{3} \mathrm{CH}_{2}\right], 34.43,29.74,22.64\left[\left(\mathrm{CH}_{2}\right)_{3} \mathrm{CH}_{2}\right]$.

(+)-(1R,2R)-3-(\{2-[(Benzyloxycarbonyl)amino]ethyl\}amino)-1-I(\{2[(benzyloxycarbonyl)amino]ethyl\}amino)carbonyl]-3-oxo-2-(hexadecanoyloxy)propyl Hexadecanoate (9): A cooled $\left(0^{\circ} \mathrm{C}\right)$ solution of $3(870 \mathrm{mg}, 1.39 \mathrm{mmol})$ in $\mathrm{CHCl}_{3}$ was treated with a solution of benzyl $\mathrm{N}$-(2-aminoethyl)carbamate $(760 \mathrm{mg}, 3.96 \mathrm{mmol})$ and 1-hydroxybenzotriazole $(376 \mathrm{mg}, 2.78 \mathrm{mmol})$ in $\mathrm{CHCl}_{3}(10 \mathrm{~mL})$. DCC $(580 \mathrm{mg}, 2.8 \mathrm{mmol})$ was then added in small portions. The reaction mixture was stirred for $15 \mathrm{~min}$ at $0{ }^{\circ} \mathrm{C}$ and then overnight at room temperature. Subsequently, it was filtered and the residue was washed with $\mathrm{CHCl}_{3}(2 \times 20 \mathrm{~mL})$. The filtrate was concentrated in vacuo and flash column chromatography $\left(\mathrm{CHCl}_{3} / \mathrm{MeOH}, 95: 5\right.$ (v/v)] gave $1.05 \mathrm{~g}(77 \%)$ of 9 as a white solid. M.p. $134{ }^{\circ} \mathrm{C}$ (decomp.). $[\alpha]_{\mathrm{D}}^{20}=+8.5\left(c=1.0, \mathrm{CHCl}_{3}\right) . \operatorname{IR}(\mathrm{KBr}): \tilde{v}=3319(\mathrm{~N}-\mathrm{H}) \mathrm{cm}^{-1}$, 3099 (C-H aromatic), 2917, 2849 (C-H alkyl), $1741[\mathrm{C}=\mathrm{O}(\mathrm{O})]$, 1692 (Am I, urethane), 1670 (Am I), 1546 (Am II), 1536 (Am II, urethane), 1170 (alkyl-O-C). ${ }^{1} \mathrm{H}$ NMR $\left(300 \mathrm{MHz}, \mathrm{CDCl}_{3}\right): \delta=$ $7.35-7.25\left(\mathrm{~m}, 10 \mathrm{H}, \mathrm{OCH}_{2} \mathrm{C}_{6} H_{5}\right), 6.71(\mathrm{~m}, 2 \mathrm{H}, 2 \times \mathrm{NH}), 5.47[\mathrm{~s}$, $2 \mathrm{H}, \mathrm{OCHC}(\mathrm{O})], 5.44(\mathrm{~m}, 2 \mathrm{H}, 2 \times \mathrm{NH}), 3.35-3.23[\mathrm{~m}, 8 \mathrm{H}, 2 \times$ $\left.\mathrm{NH}\left(\mathrm{CH}_{2}\right)_{2} \mathrm{NH}\right], 2.41-2.37\left[\mathrm{~m}, 4 \mathrm{H}, \mathrm{CH}_{2} \mathrm{C}(\mathrm{O}) \mathrm{O}\right], 1.62-1.57[\mathrm{~m}, 4$ $\left.\mathrm{H}, \mathrm{CH}_{2} \mathrm{CH}_{2} \mathrm{C}(\mathrm{O}) \mathrm{O}\right], 1.25\left(\mathrm{~m}, 48 \mathrm{H}, 2 \times \mathrm{CH}_{3} \mathrm{C}_{12} \mathrm{H}_{24} \mathrm{C}_{2} \mathrm{H}_{4}\right), 0.88(\mathrm{t}$, $\left.6 \mathrm{H}, 2 \times \mathrm{CH}_{3}\right) .{ }^{13} \mathrm{C} \mathrm{NMR}\left(75 \mathrm{MHz}, \mathrm{CDCl}_{3}\right): \delta=172.26[2 \times$ $\left.\mathrm{C}(\mathrm{O}) \mathrm{OCH}], 166.92(2 \times \mathrm{CONH}), 157.21[2 \times \mathrm{NHC} \mathrm{O}) \mathrm{OCH}_{2}\right]$, $136.33\left(2 \times\right.$ quat. $\left.\mathrm{OC}_{6} \mathrm{H}_{5}\right), 128.48\left(4 \times m-C_{6} \mathrm{H}_{5}\right), 128.10(2 \times p$ $\left.C_{6} \mathrm{H}_{5}\right), 128.03\left(4 \times o-C_{6} \mathrm{H}_{5}\right), 72.15[2 \times \mathrm{OCHC}(\mathrm{O}) \mathrm{O}], 66.81(2 \times$ $\left.\mathrm{OCH}_{2} \mathrm{C}_{6} \mathrm{H}_{5}\right), \quad 40.48 \quad\left[2 \times \mathrm{CH}_{2} \mathrm{CH}_{2} \mathrm{NC}(\mathrm{O}) \mathrm{O}\right], \quad 39.98 \quad[2 \times$ $\left.\mathrm{CH}_{2} \mathrm{CH}_{2} \mathrm{NC}(\mathrm{O}) \mathrm{O}\right], 33.76,31.92,30.28,29.67,29.49,29.31,29.07$, 25.57, 24.91, 24.64, 22.66, [2 $\left.\times \mathrm{CH}_{3}\left(\mathrm{CH}_{2}\right)_{14}\right], 14.09\left(2 \times \mathrm{CH}_{3}\right)$. $\mathrm{C}_{56} \mathrm{H}_{90} \mathrm{~N}_{4} \mathrm{O}_{10}$ (978.9): C 68.68, H 9.26, N 5.72; found C 68.70, H 9.46, N 5.78 .

(+)-[2-(\{(2R,3R)-4-[(Ammonioethyl)amino]-2,3-bis(hexadecanoyloxy)-4-oxobutanoyl\}amino)ethyl|ammonium Dibromide (10): $\mathrm{HBr}$ in acetic acid [15 mL, 33\%, (v/v)] was added to 9 (450 mg, $0.46 \mathrm{mmol})$ 
and the reaction mixture stirred for $15 \mathrm{~min}$ at room temperature. Diethyl ether $(10 \mathrm{~mL})$ was added and the white precipitate was filtered and washed with diethyl ether $(3 \times 20 \mathrm{~mL})$. Recrystallization from $\mathrm{MeOH}$ gave $219 \mathrm{mg}(53 \%)$ of $\mathbf{1 0}$ as a white solid. M.p. $104{ }^{\circ} \mathrm{C}$ (decomp). $[\alpha]_{\mathrm{D}}^{20}=4.7(c=1.0, \mathrm{MeOH}) . \operatorname{IR}(\mathrm{KBr}): \tilde{v}=3370$ $(\mathrm{N}-\mathrm{H}) \mathrm{cm}^{-1}, 3050\left(\mathrm{~N}-\mathrm{H}, \mathrm{NH}_{3}{ }^{+}\right), 2918,2850(\mathrm{CH}$ alkyl $), 1745$ $[\mathrm{C}=\mathrm{O}(\mathrm{O})], 1641$ (Am I), 1547 (Am II), 1162 [alkyl-O-C(O)]. ${ }^{1} \mathrm{H}$ NMR (300 MHz, CD $\left.\mathrm{CD}_{3} \mathrm{OD}\right): \delta=5.49[\mathrm{~s}, 2 \mathrm{H}, 2 \times \mathrm{OCHC}(\mathrm{O})], 4.51$ $[\mathrm{m}, 2 \mathrm{H}, 2 \times \mathrm{C}(\mathrm{O}) \mathrm{NH}], 3.47-3.38\left(\mathrm{~m}, 4 \mathrm{H}, 2 \times \mathrm{CH}_{2} \mathrm{CH}_{2} \mathrm{NH}_{3}{ }^{+}\right)$, $2.99\left(\mathrm{t}, J=6.0 \mathrm{~Hz}, 4 \mathrm{H}, 2 \times \mathrm{CH}_{2} \mathrm{CH}_{2} \mathrm{NH}_{3}{ }^{+}\right), 2.40[\mathrm{dt}, J=7.5 \mathrm{~Hz}$, $\left.2 \times \mathrm{CH}_{2} \mathrm{C}(\mathrm{O}) \mathrm{O}\right], 1.58-1.54\left[\mathrm{~m}, 4 \mathrm{H}, 2 \times \mathrm{CH}_{2} \mathrm{CH}_{2} \mathrm{C}(\mathrm{O}) \mathrm{O}\right], 1.25$ $\left[\mathrm{m}, 48 \mathrm{H}, 2 \times \mathrm{CH}_{3}\left(\mathrm{CH}_{2}\right)_{12} \mathrm{C}_{2} \mathrm{H}_{4}\right], 0.83(\mathrm{t}, J=6.3 \mathrm{~Hz}, 6 \mathrm{H}, 2 \times$ $\left.\mathrm{CH}_{3}\right) \cdot{ }^{13} \mathrm{C} \mathrm{NMR}\left(75 \mathrm{MHz}, \mathrm{CD}_{3} \mathrm{OD}\right): \delta=174.23[2 \times \mathrm{C}(\mathrm{O}) \mathrm{OCH}]$, $170.01[2 \times \mathrm{CHC}(\mathrm{O}) \mathrm{NH}], 73.63[2 \times \mathrm{OCHC}(\mathrm{O}) \mathrm{NH}], 40.68(2 \times$ $\left.\mathrm{CH}_{2} \mathrm{CH}_{2} \mathrm{NH}_{3}{ }^{+}\right), 38.13\left(2 \times \mathrm{CH}_{2} \mathrm{CH}_{2} \mathrm{NH}_{3}{ }^{+}\right), 34.62\left[\mathrm{CH}_{2} \mathrm{C}(\mathrm{O}) \mathrm{O}\right]$, $33.09,30.82,30.68,30.49,30.20\left[2 \times \mathrm{CH}_{3}\left(\mathrm{CH}_{2}\right)_{14}\right], 14.45(2 \times$ $\mathrm{CH}_{3}$ ). $\mathrm{C}_{40} \mathrm{H}_{80} \mathrm{Br}_{2} \mathrm{~N}_{4} \mathrm{O}_{6} \cdot 1.5 \mathrm{H}_{2} \mathrm{O}$ (899.7): C 53.39, H 9.18, N 6.22; found $\mathrm{C} 53.39, \mathrm{H} 9.00, \mathrm{~N} 6.23$.

(1R,2R)-3-(\{I(1R)-1-(Aminocarbonyl)-5-[(benzyloxycarbonyl)amino]pentyl\}amino)-1-[(\{(1R)-1-(aminocarbonyl)-5-[(benzyloxycarbonyl)aminolpentyl $\}$ amino)carbonyl]-2-(hexadecanoyloxy)-3-oxopropyl Hexadecanoate (11): A cooled $\left(0{ }^{\circ} \mathrm{C}\right)$ solution of $3(713 \mathrm{mg}, 1.13 \mathrm{mmol})$ in $\mathrm{CHCl}_{3}(10 \mathrm{~mL})$ was treated with a mixture of 1-hydroxybenzotriazole $(368 \mathrm{mg}, 2.85 \mathrm{mmol})$, triethylamine $(0.54 \mathrm{~mL}, 2.9 \mathrm{mmol})$, and amine $6(1.29 \mathrm{~g}, 2.85 \mathrm{mmol})$ in $\mathrm{CHCl}_{3}$ (10 mL), followed by a solution of $N$-(3-dimethylamino)propyl- $N^{\prime}$ ethylcarbodiimide $(403 \mathrm{mg}, 2.85 \mathrm{mmol})$ in $\mathrm{CHCl}_{3}(10 \mathrm{~mL})$. The reaction mixture was stirred for $10 \mathrm{~min}$ at $0{ }^{\circ} \mathrm{C}$ and left overnight at room temperature, diluted with $\mathrm{CHCl}_{3}$, and subsequently washed with $1.5 \mathrm{~N} \mathrm{HCl}, 10 \%$ (w/v) $\mathrm{NaHCO}_{3}$ solution, and brine, dried $\left(\mathrm{MgSO}_{4}\right)$ and concentrated in vacuo. The residue was purified by flash column chromatography $\left(\mathrm{SiO}_{2}\right.$, gradient $\mathrm{CHCl}_{3} / \mathrm{MeOH}, 98: 2$ to $95: 5)$ to afford $350 \mathrm{mg}(27 \%)$ of $\mathbf{1 1}$ as a colourless oil. $\mathrm{IR}(\mathrm{KBr})$ : $\tilde{v}=3274 \mathrm{~cm}^{-1}(\mathrm{~N}-\mathrm{H}), 2919,2850(\mathrm{C}-\mathrm{H}$, alkyl $), 1745[\mathrm{C}=\mathrm{O}(\mathrm{O})]$, 1690 (Am I, urethane), 1660 (Am I, primary), 1650 (Am I, secondary), 1548 (Am II). ${ }^{1} \mathrm{H}$ NMR (300 MHz, $\left.\mathrm{CDCl}_{3}\right): \delta=7.32(\mathrm{~m}, 10$ $\left.\mathrm{H}, 2 \times \mathrm{C}_{6} H_{5}\right), 5.48(\mathrm{~s}, 2 \mathrm{H}, 2 \times \mathrm{OCOCH}), 5.08(\mathrm{~s}, 4 \mathrm{H}, 2 \times$ $\left.\mathrm{CH}_{2} \mathrm{O}\right), 4.43\left(\mathrm{~m}, 2 \mathrm{H}, 2 \times \mathrm{CHCONH}_{2}\right), 3.21-3.15(\mathrm{~m}, 4 \mathrm{H}, 2$ $\left.\times \mathrm{CH}_{2} \mathrm{NHCOOC}_{6} \mathrm{H}_{5}\right), 2.37\left(\mathrm{t}, J=7.5 \mathrm{~Hz}, 4 \mathrm{H}, 2 \times \mathrm{CH}_{2} \mathrm{COO}\right)$, 1.61-1.25 [m, $\left.64 \mathrm{H}, 2 \times\left(\mathrm{CH}_{2}\right)_{3} \mathrm{CH}_{2}, 2 \times \mathrm{CH}_{3}\left(\mathrm{CH}_{2}\right)_{13} \mathrm{CH}_{2} \mathrm{CO}\right]$, $0.87\left(\mathrm{t}, J=6.9 \mathrm{~Hz}, 2 \times \mathrm{CH}_{3}\right) \cdot{ }^{13} \mathrm{C} \mathrm{NMR}\left(75 \mathrm{MHz}, \mathrm{CDCl}_{3}\right): \delta=$ $174.58\left(2 \times \mathrm{CONH}_{2}\right), 172.56[2 \times \mathrm{CHC}(\mathrm{O}) \mathrm{NH}], 166.18[2 \times$ $C(\mathrm{O}) \mathrm{O}], 156.68\left[2 \times \mathrm{NHC}(\mathrm{O}) \mathrm{OC}_{6} \mathrm{H}_{5}\right], 137.11\left(2 \times\right.$ quat. $\left.C_{6} \mathrm{H}_{5}\right)$, 128.51, 128.08, $127.99\left(o-, m-, p-C_{6} \mathrm{H}_{5}\right), 72.37$ ( $2 \times C$ HOOC $), 66.58$ $\left(2 \times \mathrm{OCH}_{2} \mathrm{C}_{6} \mathrm{H}_{5}\right), \quad 52.73\left(2 \times \mathrm{CHCONH}_{2}\right), 40.31(2 \times$ $\left.\mathrm{CH}_{2} \mathrm{NHCOOCH}_{2} \mathrm{C}_{6} \mathrm{H}_{5}\right), 33.75\left(2 \times \mathrm{CH}_{2} \mathrm{COO}\right), 31.91,29.70$, $29.53,29.35,29.19,29.09,25.63,24.68,22.68\left[2 \times\left(\mathrm{CH}_{2}\right)_{3} \mathrm{CH}_{2}, 2\right.$ $\left.\times \mathrm{CH}_{3}\left(\mathrm{CH}_{2}\right)_{13}\right], 14.11\left(2 \times \mathrm{CH}_{3}\right)$.

(-)-I(5R)-6-Amino-5-\{I(2R,3R)-4-\{I(1R)-1-(aminocarbonyl)-5ammoniopentyl]amino\}-2,3-bis(hexadecanoyloxy)-4-oxobutanoyl]amino\}-6-oxohexyl)ammonium Dibromide (12): Compound 12 (192 mg, 60\%) was obtained from 11 by using the same procedure as for the preparation of $\mathbf{1 0}$ from $\mathbf{9}$, as a white solid. M.p. $189^{\circ}$ (decomp.). $[\alpha]_{\mathrm{D}}^{20}=-2.63(c=0.97, \mathrm{MeOH}) . \operatorname{IR}(\mathrm{KBr}): \tilde{v}=3275$ $(\mathrm{N}-\mathrm{H}) \mathrm{cm}^{-1}, 2919,2849$ (C-H alkyl). ${ }^{1} \mathrm{H}$ NMR $(300 \mathrm{MHz}$, $\left.\mathrm{CD}_{3} \mathrm{OD}\right): \delta=5.43$ (s, $\left.1 \mathrm{H}, 2 \times \mathrm{OCHCO}\right), 4.27$ (dd, $J=4.9, J=$ $\left.8.9 \mathrm{~Hz}, 2 \mathrm{H}, 2 \times \mathrm{CHCONH}_{2}\right), 2.83(\mathrm{t}, J=7.6 \mathrm{~Hz}, 4 \mathrm{H}, 2 \times$ $\left.\mathrm{CH}_{2} \mathrm{NH}_{3}{ }^{+}\right), 2.39\left(\mathrm{t}, \mathrm{J}=7.5 \mathrm{~Hz}, 4 \mathrm{H}, 2 \times \mathrm{CH}_{2} \mathrm{COO}\right), 1.86-1.77$ $\left[\mathrm{m}, 2 \mathrm{H}, 2 \times \mathrm{CH}\left(\mathrm{CH}_{2}\right)_{3} \mathrm{NH}_{3}{ }^{+}\right], 1.68-1.52(\mathrm{~m}, 10 \mathrm{H}, 2 \times$ $\left.\mathrm{CH} H C H_{2} \mathrm{CH}_{2} \mathrm{CH}_{2} \mathrm{NH}_{3}{ }^{+}, 2 \times \mathrm{CH}_{2} \mathrm{CH}_{2} \mathrm{COO}\right), 1.39-1.20[\mathrm{~m}, 52$ $\left.\mathrm{H}, 2 \times \mathrm{CH}_{2} \mathrm{CH}_{2} \mathrm{CH}_{2} \mathrm{CH}_{2} \mathrm{NH}_{3}{ }^{+}, 2 \times \mathrm{CH}_{3}\left(\mathrm{CH}_{2}\right)_{12}\right], 0.81(\mathrm{t}, \mathrm{J}=$ $\left.6.9 \mathrm{~Hz}, 6 \mathrm{H}, 2 \times \mathrm{CH}_{3}\right) .{ }^{13} \mathrm{C} \mathrm{NMR}(75 \mathrm{MHz}, \mathrm{MeOD}): \delta=175.81$
$(2 \times \mathrm{COO}), 174.22\left(2 \times \mathrm{CONH}_{2}\right), 168.57(2 \times \mathrm{CONH}), 73.84(2$ $\times \mathrm{OCHCO}), 53.79\left(2 \times \mathrm{CHCONH}_{2}\right), 40.53\left(2 \times \mathrm{CH}_{2} \mathrm{NH}_{3}{ }^{+}\right)$, $34.57,33.07,32.35,30.81,30.67,30.46,30.19,27.98,25.84,23.72$, $23.54\left[2 \times \mathrm{CH}_{3}\left(\mathrm{CH}_{2}\right)_{14}, 2 \times\left(\mathrm{CH}_{2}\right)_{3} \mathrm{CH}_{2}\right], 14.43\left(2 \times \mathrm{CH}_{3}\right)$. $\mathrm{C}_{48} \mathrm{H}_{94} \mathrm{Br}_{2} \mathrm{~N}_{6} \mathrm{O}_{8} \cdot 0.5 \mathrm{H}_{2} \mathrm{O}$ (1052.1): calcd. C 55.27, $\mathrm{H}$ 9.08, N 8.06; found $\mathrm{C} 55.04, \mathrm{H} 8.73, \mathrm{~N} 8.07$.

$(1 R, 2 R)-3-(\{(1 S)-5-[($ Benzyloxycarbonyl)amino]-1-I(\{2-I(benzyloxycarbonyl)amino]ethyl\}amino)carbonyl|pentyl\}amino)-1-I( $\{(1 S)-$ 5-[(benzyloxycarbonyl)amino]-1-I(\{2-[(benzyloxycarbonyl)amino]ethyl\} amino)carbonyl|pentyl\}amino)carbonyll-2-(hexadecanoyloxy)3-oxopropyl Hexadecanoate (13): Compound 13 (342 mg, 60\%) was obtained from $\mathbf{3}$ and $\mathbf{8}$ by using the same procedure as described for the preparation of $\mathbf{1 1}$ from $\mathbf{3}$ and $\mathbf{6}$. IR $(\mathrm{KBr}): \tilde{v}=3324,3278$ $(\mathrm{N}-\mathrm{H}) \mathrm{cm}^{-1}, 3068,3034(\mathrm{C}-\mathrm{H}$, aromatic), 2921, $2850(\mathrm{C}-\mathrm{H}$, alkyl), $1744[\mathrm{C}=\mathrm{O}(\mathrm{O})], 1689$ (Am I, urethane), 1648 (Am I), 1544 (Am II). ${ }^{1} \mathrm{H}$ NMR (300 MHz, $\mathrm{CDCl}_{3} / \mathrm{CD}_{3} \mathrm{OD}$ ): $\delta=7.68$ (br. s, 2 $\mathrm{H}, \mathrm{NH}), 7.45-7.28\left(\mathrm{~m}, 20 \mathrm{H}, 4 \times \mathrm{C}_{6} H_{5}\right), 6.50$ (br. s, $2 \mathrm{H}, \mathrm{NH}$ ), 6.27 (br. s, $2 \mathrm{H}, \mathrm{NH}$ ), 5.44 (s, $2 \mathrm{H}, \mathrm{OCHCO}$ ), 5.07 (s, $8 \mathrm{H}, 4 \times$ $\mathrm{OCH}_{2} \mathrm{C}_{6} \mathrm{H}_{5}$ ), 4.26 (br. s, $2 \mathrm{H}, \mathrm{NH}$ ), 3.29-3.15[m, $10 \mathrm{H}, 2 \times$ $\left.\mathrm{NHCHCONH}, 2 \times\left(\mathrm{CH}_{2}\right)_{2}\right], 3.13-3.10\left[\mathrm{~m}, 4 \mathrm{H}, 2 \times\left(\mathrm{CH}_{2}\right)_{3} \mathrm{CH}_{2}\right]$, 2.43-2.41 (m, $\left.4 \mathrm{H}, 2 \times \mathrm{CH}_{2} \mathrm{COO}\right), 1.85-1.00[\mathrm{~m}, 64 \mathrm{H}, 2 \times$ $\left.\left(\mathrm{CH}_{2}\right)_{3} \mathrm{CH}_{2}, \mathrm{CH}_{3}\left(\mathrm{CH}_{2}\right)_{13}\right], 0.87\left(\mathrm{t}, \mathrm{J}=6.7 \mathrm{~Hz}, 2 \times \mathrm{CH}_{3}\right) .{ }^{13} \mathrm{C} \mathrm{NMR}$ $(75 \mathrm{MHz}, \mathrm{MeOD}): \delta=172.62(\mathrm{COO}), 171.77(2 \times \mathrm{CHCONH})$, $166.55(2 \times \mathrm{OCHCONH}), 156.92\left(4 \times \mathrm{NHCOOC}_{6} \mathrm{H}_{5}\right), 136.23(4$ $\times$ quat. $\left.C_{6} \mathrm{H}_{5}\right), 127.92,127.47,127.26\left(4 \times o-, m-, p-\mathrm{C}_{6} \mathrm{H}_{5}\right), 72.15$ $(2 \times \mathrm{OCOCHCONH}), 66.11,65.98\left(4 \times \mathrm{CH}_{2} \mathrm{C}_{6} \mathrm{H}_{5}\right), 52.78(2 \times$ $\mathrm{NHCHCONH}), 39.19,39.07,33.18,33.10,31.41,29.18$ 29.02, 28.84, 28.79, 28.58, 22.14 $\left[2 \times\left(\mathrm{CH}_{2}\right)_{2}, 2 \times\left(\mathrm{CH}_{2}\right)_{3} \mathrm{CH}_{2}, 2 \times\right.$ $\left.\mathrm{CH}_{3}\left(\mathrm{CH}_{2}\right)_{14}\right], 13.35\left(2 \times \mathrm{CH}_{3}\right)$.

(-)-(2-\{I(2S)-6-Ammonio-2-\{I(2R,3R)-4-\{I(1S)-5-ammonio-1-\{I(2ammonioethyl)amino]carbonyl $\}$ pentyl]amino\}-2,3-bis(hexadecanoyloxy)-4-oxobutanoyl|amino\} hexanoyl|amino\}ethyl)ammonium Tetrabromide (14): Compound $\mathbf{1 4}(205 \mathrm{mg}, 60 \%)$ was obtained from $\mathbf{1 3}$, by using the same procedure as for the preparation of $\mathbf{1 0}$ from $\mathbf{9}$, as a white solid. M.p. $205^{\circ}$ (decomp.). $[\alpha]_{\mathrm{D}}^{20}=-0.95(c=1.0$, $\mathrm{MeOH})$. IR (KBr): $\tilde{v}=3428,3275(\mathrm{~N}-\mathrm{H}$, amides $) \mathrm{cm}^{-1}, 2919$, 2849 (C-H, alkyl), 1734 [C=O(O)], 1659 (Am I), 1556 (Am II). ${ }^{1} \mathrm{H}$ NMR (300 MHz, $\left.\mathrm{CD}_{3} \mathrm{OD}\right): \delta=5.57$ (s, $\left.2 \mathrm{H}, 2 \times \mathrm{OCHCONH}\right)$, $4.25(\mathrm{dd}, J=4.9 \mathrm{~Hz}, 2 \mathrm{H}, \mathrm{NHCH}), 3.47(\mathrm{~m}, 4 \mathrm{H}, 2 \times$ $\left.\mathrm{CH}_{2} \mathrm{CH}_{2} \mathrm{NH}_{3}{ }^{+}\right), 3.05\left(\mathrm{t}, \mathrm{J}=5.8 \mathrm{~Hz}, 4 \mathrm{H}, 2 \times \mathrm{CH}_{2} \mathrm{CH}_{2} \mathrm{NH}_{3}{ }^{+}\right)$, $3.11\left[\mathrm{t}, J=7.6 \mathrm{~Hz}, 4 \mathrm{H}, 2 \times\left(\mathrm{CH}_{2}\right)_{3} \mathrm{CH}_{2}\right], 2.46(\mathrm{dt}, J=7.5 \mathrm{~Hz}, 4$ $\left.\mathrm{H}, 2 \times \mathrm{CH}_{2} \mathrm{COO}\right), 2.00-1.58\left(\mathrm{~m}, 12 \mathrm{H}, 2 \times \mathrm{CH}_{2} \mathrm{CH}_{2} \mathrm{CH}_{2} \mathrm{CH}_{2}, 2\right.$ $\left.\times \mathrm{CH}_{2} \mathrm{CH}_{2} \mathrm{COO}\right), 1.50-1.25\left[\mathrm{~m}, 52 \mathrm{H}, 2 \times \mathrm{CH}_{2} \mathrm{CH}_{2} \mathrm{CH}_{2} \mathrm{CH}_{2}, 2\right.$ $\left.\times \mathrm{CH}_{3}\left(\mathrm{CH}_{2}\right)_{12}\right], 1.06\left(\mathrm{t}, J=6.8 \mathrm{~Hz}, 6 \mathrm{H}, 2 \times \mathrm{CH}_{3}\right),{ }^{13} \mathrm{C} \mathrm{NMR}$ (75 MHz, $\left.\mathrm{CD}_{3} \mathrm{OD}\right): \delta=174.48(2 \times \mathrm{COO}), 169.13(4 \times \mathrm{CONH})$, 73.84 (OCHCO), $54.96(2 \times \mathrm{CHCONH}), 40.71,40.51(4 \times$ $\mathrm{CH}_{2} \mathrm{NH}_{3}{ }^{+}$), 38.26, 34.76, 33.07, 31.63, 30.83, 30.50, 30.26, 28.00, 25.91, 23.87, 23.73 $\left[2 \times \mathrm{CH}_{2} \mathrm{CH}_{2} \mathrm{NH}_{3}{ }^{+}, 2 \times\left(\mathrm{CH}_{2}\right)_{3} \mathrm{CH}_{2}\right.$, $\left.\mathrm{CH}_{3}\left(\mathrm{CH}_{2}\right)_{14}\right], 14.43\left(2 \times \mathrm{CH}_{3}\right) \cdot \mathrm{C}_{52} \mathrm{H}_{106} \mathrm{Br}_{4} \mathrm{~N}_{8} \mathrm{O}_{8} \cdot 2.5 \mathrm{H}_{2} \mathrm{O}(1336.1)$ : calcd. C 46.75, H 8.18, N 8.39; found C 46.83, H 7.90, N 8.32.

Electron Microscopy: A $2 \%(w / v)$ methanolic solution $(50 \mu \mathrm{L})$ of $\mathbf{1 0}, \mathbf{1 2}$, or 14 (typical $1 \mathrm{mg}$ ) was injected into $1.0 \mathrm{~mL}$ of water at 60 ${ }^{\circ} \mathrm{C}$, adjusted to $\mathrm{pH}=7.0$ with $10 \mathrm{~mm}$ PIPES, and sonicated at this temperature for $30 \mathrm{~min}$. The sonicator was an Elma Transsonic Digital T480/H-2 (power approx. $600 \mathrm{~W}$ ). The dispersion was cooled to room temperature and left to stand for $24 \mathrm{~h}$ before EM samples were prepared. Pt-shadowed samples were prepared by bringing a drop of the dispersion onto a Formvar carbon-coated microscope grid. The excess of the dispersion was removed by blotting with a filter paper after $1 \mathrm{~min}$, and the sample was shadowed under an angle of $45^{\circ}$ by evaporation of Pt. All samples were studied with a Philips TEM201 microscope $(60 \mathrm{kV})$. 
Monolayer Experiments: Monolayer experiments were performed with a themostatted double barrier Riegler \& Kirstein trough of dimensions $6 \times 25 \mathrm{~cm}$ with a compression speed of $7.0 \mathrm{~cm}^{2} / \mathrm{min}$. The film balance was housed in a Laminar Downflow cabinet (type DLF 460, Clean air techniek, Woerden). The surface pressure was measured using Wilhelmy plates and octadecanol was used for calibration. The surfactant was spread using a chloroform/methanol (9:1, v/v) solution (ca. $10 \mu \mathrm{L}, 1 \mathrm{mg} / \mathrm{ml}$ ); after $10 \mathrm{~min}$, compression was started.

UV and Circular Dichroism: The liposomal transfection agent $N$ (2,3-dioleoyloxypropyl)- $N, N, N$-trimethylammonium methylsulfate (dioleoyltrimethylammonium propane, DOTAP) was purchased from Boehringer Mannheim. $\lambda$-Phage DNA (Escherichia coli W3110, strain $\lambda c 1857$, Sam 7, 48502 base pairs) was purchased from Sigma, cat. no. D9768. Absorption spectra were recorded by using a Perkin-Elmer Lambda $6 \mathrm{UV} /$ Vis spectrometer and CD measurements were performed with a Jasco-600 spectropolarimeter. The effects of additions of increasing amounts of the surfactants on the CD spectra of $\lambda$-phage DNA $(43.3 \mu \mathrm{M}$, base molar, one $\mathrm{A}_{260}$ unit is equivalent to $40 \mu \mathrm{g}$ of DNA) were monitored at $25^{\circ} \mathrm{C}$ in a $10 \mathrm{~mm}$ PIPES ( $\mathrm{pH}=7.0$ ) buffer, and the spectral changes were recorded after each addition (typically $10 \mu \mathrm{L}$ of the surfactant dispersions, prepared as described in the electron microscopy section).

Agarose Gel Electrophoresis: ${ }^{[7,8]}$ The pCMV-luciferase plasmid DNA used in the transfection experiments (see below) was incubated with ethidium bromide (3,8-diamino-5-ethyl-6-phenylphenanthridium bromide) in water for $15 \mathrm{~min}$ at room temperature. Gemini surfactants in water were then added in various concentrations up to $1 \mathrm{mg} / \mathrm{ml}$ (total volume $20 \mu \mathrm{L}$ ) and the mixture was incubated for another $30 \mathrm{~min}$ at room temperature. After addition of a loading buffer, the samples were subjected to electrophoresis at $75 \mathrm{~V}$ (constant) on a $0.6 \%$ agarose gel in a $1 \mathrm{x}$ TBE (tris/borate/EDTA) buffer system. After approx. 1.2-2 h, the gel run was stopped, and the gel visualized with UV light. The loss of the ethidium bromide fluorescence was taken as a measure of the capacity of the surfactant to release the probe from the fluorescent complex with DNA.

Gene Transfection and Cytotoxicity: ${ }^{[7,8]}$ The adherent cell line $\mathrm{CHO}-\mathrm{K} 1^{[38]}$ was used for all transfection measurements. Complete medium consisted of MEM alpha medium supplemented with $10 \%$ $\mathrm{v} / \mathrm{v}$ foetal bovine serum and 1x L-Glutamine. All media and supplements, including the reference cytofectin LipofectAMINE Plus ${ }^{\mathrm{TM}}$, were obtained from Life Technologies. Stable transfected cell lines expressing $\beta$-galactosidase were generated by cotransfection of the plasmid pSV- $\beta$-Galactosidase Control Vector (Promega) with the plasmid Selecta Vecta-Neo (R\&D Systems) in a 10:1 ratio. Following G418 (Life Technologies) selection $\left(0.8 \mathrm{mg} \mathrm{ml}^{-1}\right)$, candidate cell lines were tested for $\beta$-galactosidase activity ( $\beta$-Gal Reporter Gene Assay, chemiluminescent; Roche Diagnostics). Cells were seeded into $\mathrm{T}_{25}$ flasks (Costar) $16-18 \mathrm{~h}$ prior to transfection at an approximate density of $7.5 \times 10^{5}$ cells per flask. For transfection, $5 \mu \mathrm{g}$ of the luciferase reporter gene plasmide, pGL3-Control vector (Promega), was incubated with various concentrations of the gemini surfactants in a final volume of $400 \mu \mathrm{L}$. After $30 \mathrm{~min}$ of incubation at room temperature, $2.6 \mathrm{~mL}$ of OPTI-MEM ${ }^{\mathrm{R}}$ medium (Life Technologies) was added to the transfection mixture and the solution placed on the cells. Following a $3 \mathrm{~h}$ or overnight incubation at $37^{\circ} \mathrm{C}$, the transfection solution was replaced with complete medium and the cells incubated for a further $24 \mathrm{~h}$ at $37^{\circ} \mathrm{C}$. Cells were then harvested and seeded into 96 well plates at a density of $0.5 \times 10^{5}$ cells per well and incubated at $37{ }^{\circ} \mathrm{C}$ for a further 16-18 h. Control transfections were carried out using Lipofect-
AMINE Plus $^{\mathrm{TM}}$ (Life Technologies) according to the manufacturer's guidelines. Reporter gene assays were performed according to the manufacturer's guidelines (Roche Diagnostics) approximately $48 \mathrm{~h}$ post transfection. Luminescence was measured in a Packard TopCount NXT Microplat Scintillation and Luminescence Counter. Gene transfection activities were given on a scale from I to V, where I means "not active" ( $<1000$ counts/s), II "weak" (1000-10000 counts/s), III "active" (10000-50000 counts/s), IV "more active" (50000-150000 counts/s), and V "very active", ( $>150000$ counts/s), corresponding to the activity of LipofectAMINE Plus $^{\mathrm{TM}}$ in this assay. For assessment of the cell toxicity using flow cytometry, transfected CHO-KA cells were removed from the wells used in the transfection experiments using $0.25 \%$ trypsin solution (Life Technologies), supplemented with $2 \mu \mathrm{g} / \mathrm{ml}$ propidium iodide to label dead cells, and analysed with a Becton Dickinson FACScan flow cytometer operated by CellQuest version 3.1F (Becton Dickinson).

\section{Acknowledgments}

The authors thank Hans Adams for kind gifts of benzyl $N$-(2aminoethyl)carbamate and Lys derivatives, and Annie Roelofsen and Huub Geurts for assistance with the monolayer studies and electron microscopy, respectively. Part of this work was financed by a EC-TRM grant to the ENGEMS (European Gemini Surfactants) Network.

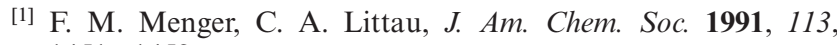
$1451-1452$.

[2] F. M. Menger, C. A. Littau, J. Am. Chem. Soc. 1993, 115, $10083-10090$.

[3] R. Zana, M. Bennraou, R. Rueff, Langmuir 1991, 7, $1072-1075$

[4] R. Zana, Y. Talmon, Nature 1993, 362, 228-230.

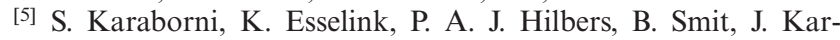
thauser, N. M. van Os, R. Zana, Science 1994, 266, 254-256.

[6] C. McGregor, C. Perrin, M. Monck, P. Camilleri, A. J. Kirby, J. Am. Chem. Soc. 2001, 123, 6215-6220.

[7] P. Camilleri, A. Kremer, A. J. Edwards, K. H. Jennings, O. Jenkins, I. Marshall, C. McGregor, W. Nevelle, S. Q. Rice, R. J. Smith, M. J. Wilkinson, A. J. Kirby, Chem. Commun. 2000, $1253-1254$.

${ }^{[8]}$ M. L. Fielden, C. Perrin, A. Kremer, M. Bergsma, M. C. Stuart, P. Camilleri, J. B. F. N. Engberts, Eur. J. Biochem. 2001, 268, 1269-1279.

[9] W. F. Anderson, Science 2000, 288, 401-409.

${ }^{[10]}$ M. Cavazzano-Calvo, S. Hacein-Bey, G. de Saint-Basile, F. Gorss, E. Yvon, P. Nusbaum, F. Selz, C. Hue, S. Certain, J.-L. Casanova, P. Bousso, F. Le Deist, A. Fischer, Science 2000, 288, 669-672.

${ }^{[11]}$ S. Lehrman, Nature 1999, 401, 517-518.

${ }^{[12]}$ P. L. Felgner, T. R. Gadek, M. Holm, R. Roman, H. W. Chan, M. Wenz, J. P. Northrop, G. M. Ringold, M. Danielsen, Proc. Natl. Acad. Sci. USA 1987, 84, 7413-7417.

${ }^{[13]}$ A. D. Miller, Angew. Chem. Int. Ed. 1998, 37, 1768-1785 and references cited therein.

${ }^{[14]}$ J. G. Smith, R. L. Walzem, J. B. German, Biochim. Biophys. Acta 1993, 1154, 327-340.

${ }^{[15]}$ Y. Xu, F. C. Szoka, Jr., Biochemistry 1996, 35, 5616-5623.

${ }^{[16]}$ M. C. Feiters, R. J. M. Nolte, Advances in Supramolecular Chemistry, vol. 6 (Ed.: G. W. Gokel), Jai Press Inc., Stamford, CT, USA, 2000, pp. 41-156.

${ }^{[17]}$ N. A. J. M. Sommerdijk, M. C. Feiters, R. J. M. Nolte, B. Zwanenburg, Recl. Trav. Chim. Pays-Bas 1994, 113, 194-200.

${ }^{[18]}$ N. A. J. M. Sommerdijk, M. H. L. Lambermon, M. C. Feiters, R. J. M. Nolte, B. Zwanenburg, Chem. Commun. 1997, $1423-1424$ 
${ }^{[19]}$ N. A. J. M. Sommerdijk, T. H. L. Hoeks, M. Synak, M. C. Feiters, R. J. M. Nolte, B. Zwanenburg, J. Am. Chem. Soc. 1997, 119, 4338-4344

${ }^{[20]}$ Y. Hu, K. A. Yamada, D. K. Chalmers, D. P. Annavajjula, D.F. Covey, J. Am. Chem. Soc. 1996, 118, 4550-4559.

${ }^{[21]}$ S. Routier, J.-L. Bernier, M. J. Waring, P. Colson, C. Houssier, C. Bailly, J. Org. Chem. 1996, 61, 2326-2331.

[22] J. N. Israelachvili, S. Marčelja, R. G. Horn, Quart. Rev. Biophys. 1980, 13, 121-200.

${ }^{[23]}$ R. E. Dickerson, H. R. Drew, B. N. Conner, R. M. Wing, A. V. Fratini, M. L. Kopka, Science 1982, 216, 475-485.

${ }^{[24]}$ W. Saenger, W. N. Hunter, O. Kennard, Nature 1986, 324, $385-388$.

${ }^{[25]}$ L. Stryer, Biochemistry, 3rd ed., W. H. Freeman and Company, New York, 1988, pp. 649-665.

${ }^{[26]}$ K. E. van Holde, W. C. Johnson, P. S. Ho, Principles of Physical Biochemistry, Prentice-Hall, Inc., Upper Saddle River, New Jersey, 1998.

[27] The complexation of this compound with DNA is well established, and the complexes have been studied by several groups (cf. refs. ${ }^{[28-30]}$, and the product information sheet of DOTAP liposomal transfection reagent from Boehringer Mannheim, cat. no. 1811177 and references cited therein).
${ }^{[28]}$ R. Leventis, J. R. Silvius, Biochim. Biophys. Acta 1990, 1023, 124-132.

${ }^{[29]}$ J. O. Rädler, I. Koltover, T. Salditt, C. R. Safinya, Science 1997, $275,810-814$.

${ }^{[30]}$ I. Koltover, T. Salditt, J. O. Rädler, C. R. Safinya, Science 1998, 281, 78-81.

[31] J. C. Wang, Proc. Natl. Acad. Sci. USA 1979, 76, 200-203.

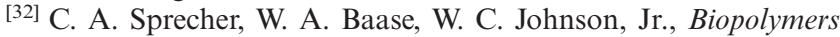
1979, 18, 1009--1019.

${ }^{[33]}$ S. Hanlon, S. Brudno, T. T. Wu, B. Wolf, Biochemistry 1975, 14, $1648-1660$.

${ }^{[34]}$ T. Akao, T. Fukumoto, H. Ihara, A. Ito, FEBS Lett. 1996, $391,215-218$.

${ }^{[35]}$ N. J. Zuidam, Y. Barenholz, A. Minsky, FEBS Lett. 1999, 457, 419-422.

${ }^{[36]}$ M. I. Gurr, A. T. James, Lipid Biochemistry, 2nd ed., Chapman and Hall, London, 1975.

[37] J. Wang, X. Guo, Y. Xu, L. Barron, F. C. Szoka, Jr., J. Med. Chem. 1998, 41, 2207-2215.

${ }^{[38]}$ T. T. Puck, S. J. Ciecura, A. Robinson, J. Exp. Med. 1958, 108, 945-959.

Received June 18, 2001

[O01293] 